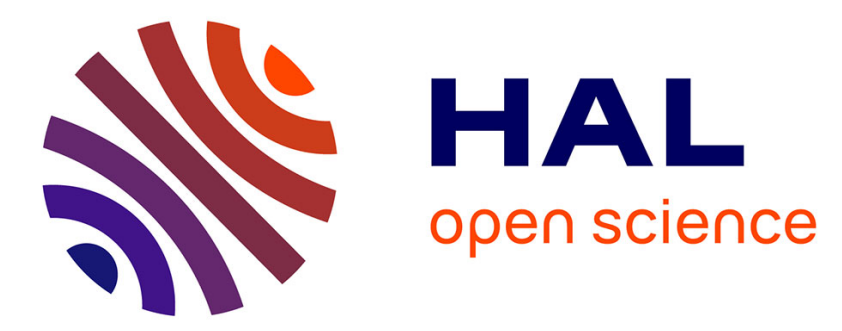

\title{
Arc Deformation and Marginal Basin Opening: Japan Sea as a Case Study
}

Laurent Jolivet, Philippe Huchon, Xavier Le Pichon, Nicolas Chamot-Rooke, Jean-Charles Thomas, Jean-Pierre Brun

\section{To cite this version:}

Laurent Jolivet, Philippe Huchon, Xavier Le Pichon, Nicolas Chamot-Rooke, Jean-Charles Thomas, et al.. Arc Deformation and Marginal Basin Opening: Japan Sea as a Case Study. Journal of Geophysical Research : Solid Earth, 1991, 96 (B3), pp.4367-4384. 10.1029/90JB02455 . insu-00726512

\section{HAL Id: insu-00726512 https://hal-insu.archives-ouvertes.fr/insu-00726512}

Submitted on 30 Aug 2012

HAL is a multi-disciplinary open access archive for the deposit and dissemination of scientific research documents, whether they are published or not. The documents may come from teaching and research institutions in France or abroad, or from public or private research centers.
L'archive ouverte pluridisciplinaire HAL, est destinée au dépôt et à la diffusion de documents scientifiques de niveau recherche, publiés ou non, émanant des établissements d'enseignement et de recherche français ou étrangers, des laboratoires publics ou privés. 


\title{
Arc Deformation and Marginal Basin Opening: Japan Sea as a Case Study
}

\author{
LAURENT JOLIVET AND PHIIIPPE HUCHON
}

Département de Géologie, Ecole normale supérieure,

\author{
JEAN PIERRE BRUN
}

Laboratoire de Tectonique, Universilé de Rennes I,

\section{XAVIER LE PICHON, NICOLAS CHAMOT-ROOKE AND JEAN CHARLES THOMAS}

Département de Géologie, Ecole normale supérieure,

\begin{abstract}
We discuss the opening mechanism of the Japan Sea in Miocene time using (1) tectonic and published paleornagnetic data along the eastem margin from the north of Hokkaido Island to Sado Island, (2) a mechanical model which is tested by small-scale physical modeling, and (3) crustal structure and bathymetric features in the Japan Sea which constrain our kinematic model and preopening reconstructions. Our main conclusions are the following. The eastem margin of the Japan Sea was, as a whole, a dextral shear zone about $100 \mathrm{~km}$ wide. This conclusion is supported by the existence of a ductile dextral shear zone in Central Hokkaido (Hidaka Mountains) and associated brittle deformation in westem Hokkaido and northeastem Honshu. The stress field during the opening (which ended about $12 \mathrm{Ma}$ ago at the end of the middle Miocene) changes from right-lateral transpression in the north to right-lateral transtension in the south. The westem margin, along the Korean peninsula, during the same period, also was an active dextral shear zone. Paleomagnetic results indicate that clockwise rotations occurred in the south during the opening and counterclockwise rotations in the north. We propose a model of right-lateral pull-apart deformation with clockwise rotations of rigid blocks in the southem transtensional domain and counterclockwise rotations in the transpressional one. Small-scale physical models show that the clockwise rotation in transtension is possible provided that the eastem boundary (Pacific side) is free of stress. The opening stopped and compression subsequently began about $12 \mathrm{Ma}$ ago. Finally, we show that the dextral shear, which is distributed over the whole Japan Sea area, is accommodated by N-S trending right-lateral faults and rotation of blocks located between these right-lateral faults.
\end{abstract}

\section{INTRODUCTION}

Whether marginal basin opening occurs by slab retreat [Matsuda and Uyeda, 1971; Hilde et al., 1977; Chase, 1978; Uyeda and Kanamori, 1979; Taylor and Karner, 1983; Uyeda, 1986] or by extension induced along transform faults [Hamburger and Isacks, 1988] or by intracontinental deformation [Tapponnier et al., 1982; 1986; Kimura and Tamaki, 1986], it is assumed that the adjacent arc docs not behave as a rigid body during the opening but, instead, suffers extensive deformation [Otofuji et al., 1985, Tamaki, 1985]. We propose in this paper a model for the Miocene opening of the Japan Sea (Figures 1 and 2) which is based on our study of the deformation over the whole arc and published paleomagnetic data. Earlier Otofuji et al. [1985] proposed that the Japan Sea opened by rotation without significant northsouth iranslation of southwestern and northeastern Japan, based on paleomagnetic data (see Figure 2, model 1). We oppose this "bar door" opening model for a right-lateral pullapart model which involves rotations about a nearby pole. The geometry of a typical pull-apart supposes no "spinning" of the displaced blocks [see McKenzie, 1990]. In our model a component of rotation about a nearby pole is added to the N-S translation along the major strike-slip faults. The mechanism

Copyright 1991 by the American Geophysical Union

Paper number 90JB02455.

0148-0227/91/90JB02455\$05.00 we propose for the opening is tested with small-scale experiments. Finally, this model is quantified in terms of kinematic reconstructions. We do not discuss forces which led to the opening. We address the question of how the Japan Sea opened and leave aside the question of why it opened.

\section{BACKGROUND}

Two principal methods have been used to study deformation at the scale of the Japan arc. The first method characterizes the deformation where it is localized, i.e., along the major faults, and describes the stress and strain regime. This method does not usually give an estimate of the magnitude of the displacements along the faults because clear offset markers are usually missing on both sides of the fault zone (it is indeed the case for the Japan arc). The second method uses paleomagnetic measurements within the relatively less strained blocks bounded by the major faults to obtain the amount of rotation and of latitudinal motion. These two approaches are obviously complementary.

Based on a paleomagnetic study, Kawai et al.[1971] first concluded that Japan had been bent. All the following paleomagnetic works have confirmed this early conclusion although significant discrepancies exist. For example, Otofuji et al. [1985] concluded that SW Japan has rotated clockwise between 15 and $13 \mathrm{Ma}$ by $56^{\circ}$ about a pole located in the Tsushima strait (between Kyushu and the Korea peninsula), and that NE Japan (the northern part of Japan, north of the Tanakura Tectonic line) has rotated rigidly by $47^{\circ}$ 


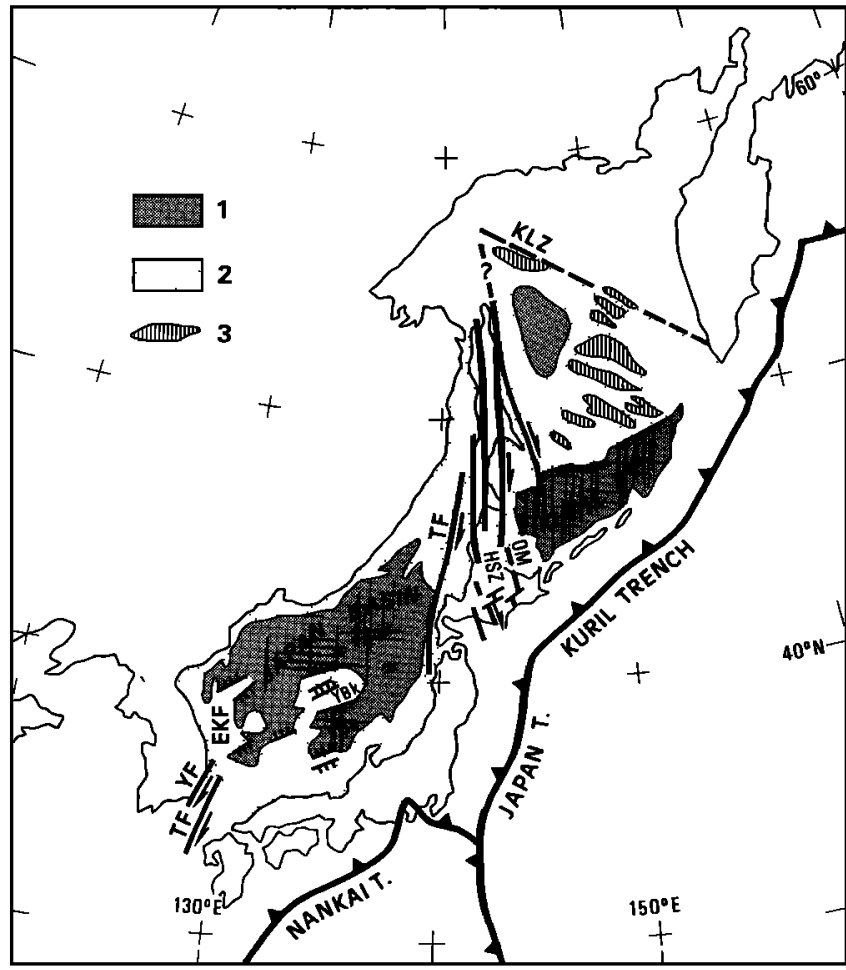

Fig. 1. Simplified structural map of the Japan Sea and Okhotsk Sea area. Key shows (1) oceanic crust, (2) thinned continental crust, (3) outcrops of basement in the Okhotsk Sea. TF is Tartary fault, HSZ is Hidaka Shear Zone, KLZ is Kashevarov Linear Zone, YF is Yangsan fault, TF is Tsushima fault, YBk is Yamato Bank, YBs is Yamato Basin, OM is Oki-Monbetsu Tectonic Line, and EKF is East Korean Fault.

counterclockwise about a pole located north of Hokkaido during the opening of the Japan Sea (Figure 2). According to Otofuji et al.[1985], these large rotations were completed within less than $1 \mathrm{Ma}$ about $15 \mathrm{Ma}$ ago. Faure and Lalevée [1987] used correlations of preopening structures to propose a similar model.

On the other hand, on the basis of observations of the deformation in northern Japan and compilation of available structural data, Lallemand and Jolivet [1985] and Jolivet et al. [1989] pointed out that major right-lateral faults were active during the opening along the eastern and westem margins (Hidaka mountains in Hokkaido and Yangsan Fault in South Korea). These authors proposed a right-lateral, pull-apart opening model (Figure 2). Earlier, Otsuki and Ehiro [1978] had used a similar approach, but with less data available at that time they reached a different conclusion.

There is an obvious conflict between the pull-apart model, which involves N-S translations, and the current interpretation of paleomagnetic data, which implies only rotations about nearby poles. In order to resolve this conflict, we present a threefold approach: (1) We establish better constraints on the deformation of the arc and its timing by characterization of the stress field and study of the behavior of the major faults during the opening. This allows us to propose a general model; (2) We test the mechanical validity of this model using small-scale analog experiments; (3) We propose preopening reconstructions of the Japan Sea based on this general mechanism with constraints from the geometry of bathymetric features.

In the initial paper proposing the pull-apart model [Lallemand and Jolivet, 1985], the eastern margin of the Japan
Sea was described as a major right-lateral shear zone for two reasons. First, the offshore structure shows a succession of N-S trending ridges and troughs bounded by vertical faults in the Tartary Strait, and right-lateral en echelon troughs along the western coast of Hokkaido and northern Honshu [Antipov et al., 1980; CCOP-IOC, 1980]. Second, a right-lateral shear zone, on land, the Hidaka Shear Zone, was active during the opening. A similar argument was used for the western margin along the eastem coast of Korea [Kang, 1981; Reedman and $U m, 1975$; Schluter and Chun, 1974]. To test this proposal we analyzed the brittle deformation along the eastem margin from Hokkaido and Rebun islands in the Tartary Strait to SW Hokkaido [Jolivet and Huchon, 1989], Oga Peninsula, Nihonkoku region and Sado island (the data collected on Sado Island are here presented for the first time) using Angelier's [1984] methods. We also considered structural data concerning the bending of Mesozoic belts in Kyushu [Murata, 1987; Fabbri et al., 1987].

These data, together with those previously discussed show that (1) the eastern margin of the Japan Sea is a right-lateral shear zone which was active from the Oligocene (?) to Middle Miocene, (2) the stress field evolved in space from a NE-SW horizontal compression in Hokkaido with simultaneous rightlateral and reverse displacements (right-lateral transpression) to a NW-SE extension in the south with coexistence of rightlateral and extensional displacements (right-lateral transtension) in agreement with the initial pull-apart model, and (3) this deformation is contemporaneous with the bending of SW Japan in the Middle Miocene. These results, considered together with the paleomagnetic data, lead to a pull-apart model with mostly clockwise rotation to the south and counterclockwise rotations to the north.

Small-scale physical experiments were undertaken to see (1) under which conditions rotations are allowed and (2) what sense of rotation can be expected in a right-lateral shear zone with a pull-apart basin opening . We tested the influence on the opening mechanism of the "free boundary" on the Pacific side: as suggested by Tapponnier and Molnar [1976] and Peltzer and Tapponnier [1988], the horizontal stress induced by subduction of the Pacific plate east of Asia is weak and the subduction does not resist to the eastward extrusion of continental blocks. We show that rotations are always clockwise, e.g., right-lateral. Rotations of small dominolike blocks between major faults and rotation of large blocks leading to basins opening are both observed. All these manifestations are enhanced by the presence of a free boundary. We conclude that the clockwise rotation of SW Japan about a pole located in the Tsushima strait is compatible in terms of mechanics with the pull-apart system. We also conclude that the counterclockwise rotation of northeast Japan is the result of the transpressional context there. We then propose a kinematic model which takes into account the geometry of the basins and major faults.

\section{SUMMARY OF THE BASIN STRUCTURE}

The structure of the Japan Sea is described in detail by Tamaki [1988]. According to Ludwig et al. [1975], Honza [1979] and Tamaki [1985], oceanic crust is distributed in three deep basins (Figure 2). The largest and deepest is the Japan basin which has the shape of a parallelogram. It is located between the Eurasian margin to the north, the Korean margin to the west, the Yamato Bank to the south, and the western margin of Honshu and Hokkaido to the east. Between the Yamato bank and the island of Honshu is the 2000-m-deep Yamato Basin. West of the Oki ridge is the Tsushima basin. Present-day tectonics involves a nascent underthrusting of the Japan Sea crust below the NE Japan arc [Fukao and Furumoto, 1975; Nakanura, 1983]. 


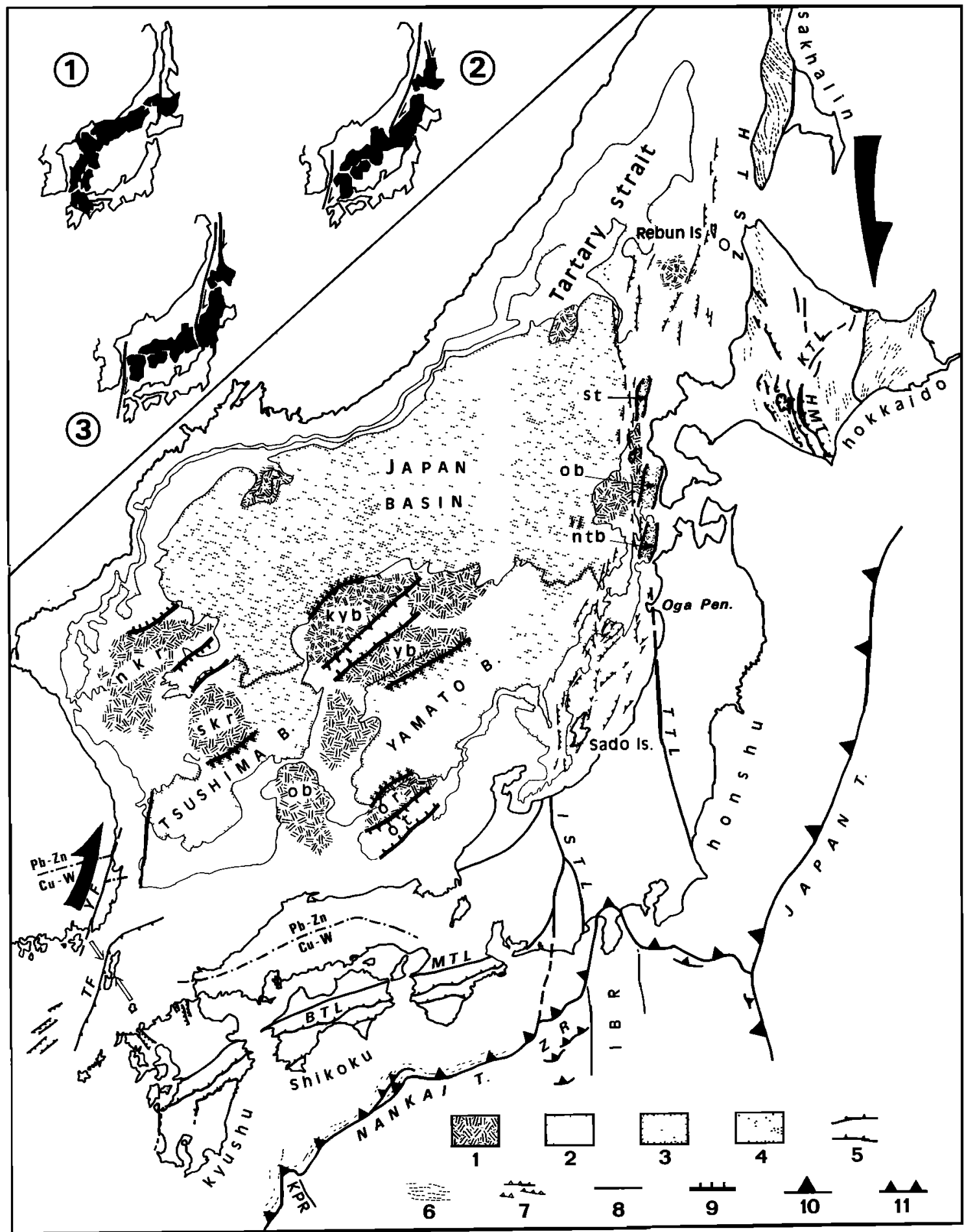

Fig. 2. Tectonic map of the Japan Sea (insert: three different models of opening, (1) Otofuji et al. [1985], (2) Jolivet et al. [1989], (3) Lallemand and Jolivet [1985]. Key shows (1) continental blocks in the Japan Sea after Tamaki [1986], (2) thinned continental crust, (3) oceanic crust, (4) recent infill of en échelon grabens on the eastern margin of the Japan Sea, (5) onland thrusts, (6) strike of folds axes after Kimura et al. [1983], (7) active offshore thrusts after Tamaki [1988], (8) strike-slip faults, (9) normal faults, (10) subduction of the Pacific plate, (11) subduction of the Philippine Sea plate. BTL is Butsuzo Tectonic Line, HMT is Hidaka Main Thrust, HTSZ is Hidaka Tartary Shear Zone [Lallemand and Jolivet, 1985], IBR is Izu-Bonin Ridge, ISTL is Itoigawa-Shizuoka Tectonic Line, KPR is Kyushu-Palau Ridge, KTL is Kamishiyubetsu Tectonic Line [Kimura et al., 1982], kyb is Kita Yamato Bank, MTL is Median Tectonic Line, nkr is North Korean Ridge, ntb is Nishi-Tsugaru Basin, ob, is Oki Bank, ob is Okushiri Basin, or is Oki Ridge, ot is Oki Through, TF is Tsushima Fault, TTL is Tanakura Tectonic Line, skr is South Korean Ridge, st is Shiribeshi Trough, yb is Yamato bank, YF is Yangsan Fault, and ZR is Zenisu Ridge. 
The magnetic structure of the basin is poorly constrained. Isezaki and Uyeda [1973], Kobayashi and Isezaki [1976], and Isezaki [1986] published contoured magnetic anomaly maps of the Japan Sea. The E-W to ENE-WSW strike of the anomalies appears clearly, at least in the Japan basin, but it is impossible to identify the anomalies with confidence. Tamaki [1988] also recognized E-W trending anomalies with a possible east to west propagation of the spreading center along strike, during a recent survey of the northern part of the Japan Sea .

The directions of the anomalies do not fit the fan shape opening of the northem Japan basin proposed by Otofuji et al. [1985] based on paleomagnetic data, which predicts fan-shaped anomalies. Instead, the spreading center seems to abut against the western margin of the Japan arc. We know that the amount of underthrusting along this margin is small [Nakamura, 1983; Tamaki and Honza, 1984], which implies that the anomalies were originaly formed perpendicular to the margin. This implies a component of strike-slip or transform along the margin.

The Yamato Bank, a rifted continental ridge, separates the Yamato and Japan Basins. The Yamato Basin is thought to be slightly younger than the Japan Basin [Hilde and Wageman, 1975]. Bathymetry and seismic profiles show that the center of the ridge is occupied by a graben trending $N 50^{\circ} \mathrm{E}$. Several parallel grabens appear in the morphology of the northern margin of SW Japan and eastem margin of Korea. Along the eastern margin of the Yamato and Japan basins, grabens are also observed trending more northerly $\left(\mathrm{N} 30^{\circ} \mathrm{E}\right)$. Several en échelon troughs (Figure 2: Shiribeshi trough, Okushiri and Nishi Tsugaru Basins) and the active E-W compression [Fukao and Furumoto, 1975] have been related by Nakamura [1983] to the nascent subduction. They actually are older extensional structures reworked by the recent compression [Tamaki and Honza, 1984; Lallemand et al., 1985]. One of these grabens crops out in the island of Sado (Figure 3). Here the faulting cuts Oligocene to Middle Miocene volcanics and volcanoclastics [Ganzawa, 1982] and is postdated by Late Miocene marine deposits.

A similar tectonic timing is recorded along the whole eastern and southern margins of the Japan Sea. For example, along the eastem coast of Korea, Schluter and Chun [1974] have shown offshore N-S trending faults parallel to the margin. Onland, NE-trending en échelon normal faults cut the Early Miocene deposits of the Yangbug group, and are covered with the Yeonil deposits of Middle Miocene age [Lee and Pouclet, 1988; Lee, 1989]. The extensional deformation thus occurred sometime during Early and Middle Miocene. This timing is in agreement with the conclusions of Tamaki [1986] which are based on heat flow, stratigraphy, and basement depth: the Japan Sea opened during Late Oligocene to Early and Middle Miocene.

Tamaki [1985] produced a map of the thickness of the crust in the Japan Sea. Oceanic and continental crust and strongly attenuated continental crust are shown from his data in figure 2 . This is a useful guide for the preopening reconstructions.

\section{ReVIEW OF ONLand Paleomagnetic Data}

\section{SW Japan.}

We shall not consider sites older than Early Tertiary in this paper. Still there is considerable argument concerning the interpretation of Early Tertiary paleomagnetic data.

Moreau et al.[1987] concluded that a strong remagnetization event may have occurred in Miocene time, but Tosha and Hamano [1988] argued against this conclusion. A widespread sampling of Miocene tuffs show easterly declinations in SW Japan [Otofuji and Matsuda, 1983; Otofuji et al., 1983; Otofuji and Matsuda, 1984; Sasajima, 1981; Otofuji et al., 1985; Hayashida, 1986]. Otofuji et al. [1985] proposed a clockwise rigid rotation $15 \mathrm{Ma}$ ago by $56^{\circ}$ about a pole located in Tsushima strait. The direction of paleomagnetic vectors are indeed fairly consistent in the area surveyed by Otofuji et al. [1985], who are in favor of a rigid-body rotation. However the declination progressively becomes more northerly to the east and northeast [Itoh, 1986; 1988; Itoh and Ito, 1988]. Hirooke et al. [1986] proposed that independent rotations of smaller blocks may have occurred. Itoh [1988] concluded that SW Japan had first rotated clockwise, as claimed by Otofuji et al., and that the eastern part of it later rotated counterclockwise to some extent due to bending of the arc along the ItoigawaShizuoka Tectonic Line. Thus the magnitudes of these rotations cannot be ascertained as we only know the resultant rotation.

Jolivet et al.[1989] proposed that these results could be interpreted as due to a rigid rotation of $\mathrm{SW}$ Japan with local rotations due to Miocene internal deformation of the arc along the Median Tectonic Line which is a Cretaceous and Paleogene left-lateral fault [Ichikawa, 1980; Otsuki and Ehiro, 1978]. But the Early to Middle Miocene deformation along this fault is not well constrained and further observations are needed to ascertain this conclusion. We shall see in the following that $30^{\circ}$ of clockwise rotation of SW Japan is required to close the basins fitting crustal features. This clockwise rotation is compatible with structural data of Kyushu Island (see below). More recently, McCabe et al. [1988] showed that Early Miocene sites of South Korea have been rotated clockwise by $20^{\circ}$. The latter data either show local rotations east of the right-lateral Yangsan fault (see later) or reduce the amount of rotation of SW Japan with respect to the Korea peninsula.

\section{NE Japan}

Otofuji et al. [1985] proposed that northeast Japan rotated counterclockwise by $47^{\circ}$ about a pole located north of Hokkaido $15 \mathrm{Ma}$ ago. Their data were obtained along the eastem coast of the Japan Sea in Oga peninsula and Asahi mountains (Nihonkoku in figure 3). Westem Asahi shows an easterly declination while eastern Asahi shows a westerly declination. They concluded that the easterly declination is due to local right-lateral rotations along the Nihonkoku-Miomote shear zone while the westerly declination is due to rigid body rotation of NE Japan. Their conclusions are mainly based on the data obtained in the Oga peninsula where a westerly declination of rocks older than $14 \mathrm{Ma}$ is observed. When plotting all the paleomagnetic directions of the Early Miocene sites published by various authors in NE Japan [figure 4 of Jolivet et al., 1989], these directions are not homogeneous and many sites are not rotated. Tosha [1983] and Tosha and Hamano [1988], after extensive sampling of the Oga peninsula, concluded that a fast rotation of about $20^{\circ}$ occurred about $15 \mathrm{Ma}$ ago. Figure 8 of their paper shows that the westerly declination decreases when the age of the sample increases. If the data are reliable this is incompatible with a rotation achieved in a single discrete stage. One must assume an early clockwise and a later counterclockwise rotation as suggested by Celaya and McCabe [1987] and Tosha and Hamano [1988] (or, alternatively, a progressive clockwise rotation by $300^{\circ}$ ). Thus the exact amount of rotation is poorly known. In this paper we relate the counterclockwise rotation to the transpressional stress field in Hokkaido and show that a total rotation of $20^{\circ}$ is compatible with the geometry of the opening.

\section{Deformation OF THE ARC DURING THE OPENING PROCESS, FIEID APPROACH}

In the following we summarize the structural data gathered along the eastern margin of the Japan Sea (for detail on the 


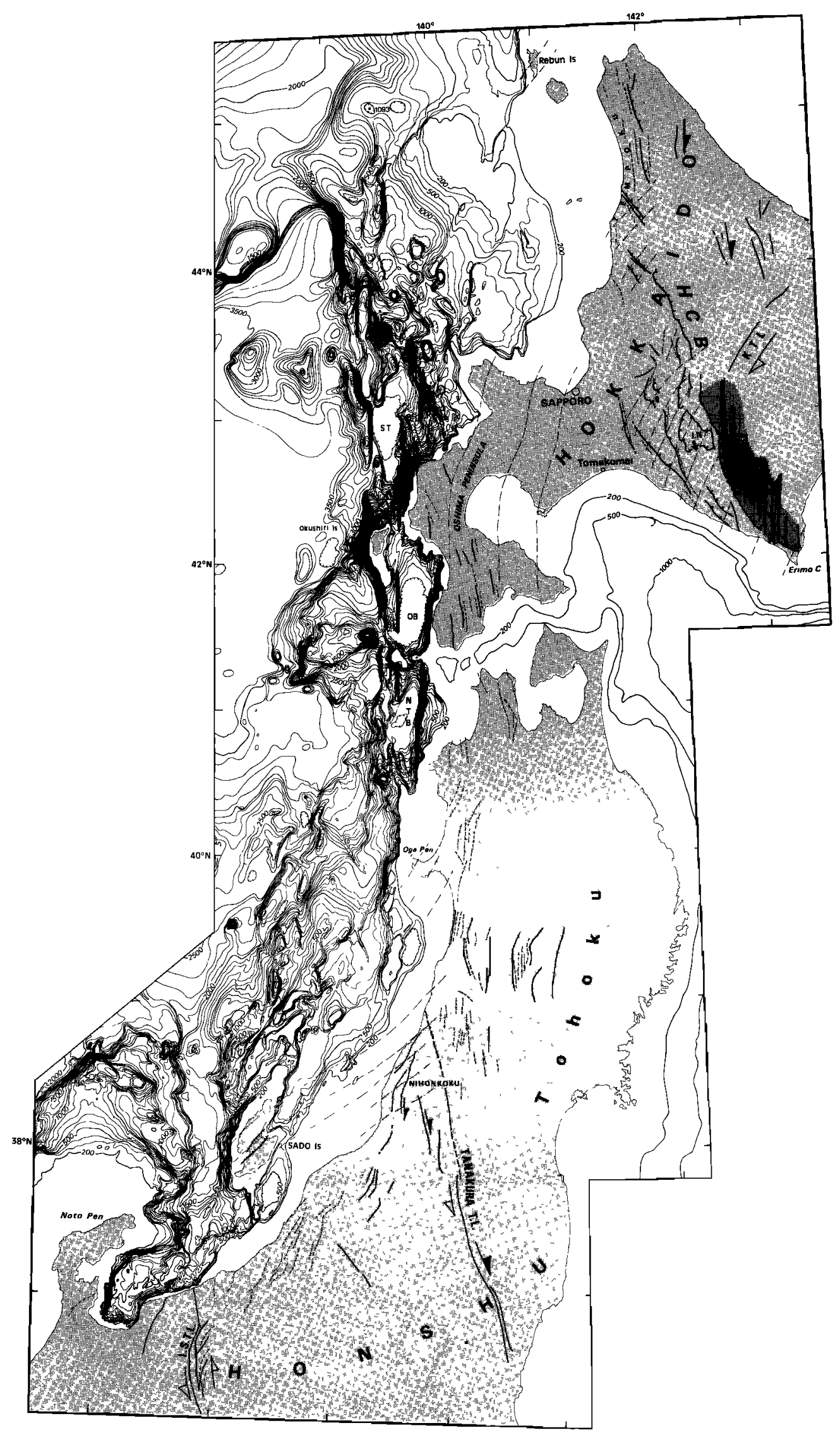

Fig. 3. Bathymetric map of the eastern margin of the Japan Sea after [Maritime Safety Agency of Japan, $1980 a, b)$ and the main onland tertiary structures [after Jolivet and Huchon, 1989; Yamaji, 1989]. IN is Iwanai nappe. Open arrows: Cretaceous motion along strike-slip faults; solid arrows: Cenozoic motion. KTL is Kamishiyubetsu Tectonic Line, OB is Okushiri Basin, NTB is Nishi Tsugaru Trough, ST is Shiribeshi Trough. Dashed curves show direction of $\sigma_{H \max }$ during Oligocene to Middle Miocene; dashed solid curves show fold axes. 
deformation in the Hokkaido Central Belt see Jolivet and Huchon [1989 and references therein]), we review published data about other areas, and we conclude with a deformation mechanism at the scale of the arc.

\section{Hokkaido Central Belt}

The present-day Hokkaido Central Belt (HCB, Figures 3 and 4) developed during the Cenozoic in two main stages. A major, right-lateral, N-S trending shear zone (Hidaka Mountains) was formed during Oligocene to Middle Miocene. It was followed by an E-W shortening which led to the formation of westward verging thrusts from Late Miocene to Present [Kimura et al., 1982; 1983; Jolivet and Miyashita, 1985; Kimura, 1986; Moriya, 1986; Watanabe, 1988; Jolivet and Huchon, 1989]. This Cenozoic succession of deformation postdates a Mesozoic stacking of nappes in high-pressure, low-temperature metamorphic conditions which is outside of the scope of this paper [Ishizuka et al., 1983; Jolivet, 1986b]. The formation of the right-lateral Hidaka Shear Zone was coeval with the emplacement of the Iwanai nappe [Jolivet and Huchon, 1989] toward the south and with the formation of en echelon folds and thrusts. These latter features can be followed all along the Hokkaido Central Belt.

The analysis of the fault sets also reveals the two successive stages of deformation and allows us to date them. The younger sets cuts all the strata including the Pliocene [see Mirani, 1978; Yamagishi and Watanabe, 1986]. The deduced principal compressive stress $\sigma_{1}$, following Angelier's [1984] method, strikes E-W. These faults are related to the recent E-W thrusting event. The older fault set is found in all strata from Middle Miocene downward. The principal compressive stress strikes NE-SW which is compatible with the right-lateral shear along the Hokkaido Central Belt. The Oligocene to Middle Miocene age of the right-lateral shear is also confirmed by the radiometric data obtained by Shibata [1968], Shibata and Ishihara [1979] and Shibata et al. [1984] on synkinematic granites and migmatites in the Hidaka Mountains (40 to 17 Ma). The Hidaka Shear Zone is made of high-temperature metamorphic rocks [Komatsu et al., 1983; Osanai et al., $1986 a ; b]$ with a vertical N-S trending foliation. The synmetamorphic strike-slip deformation reworked the original Mesozoic thrust contact between an ophiolite sequence and a granulitic basement [Jolivet, 1986a]. A high PT gradient is observed increasing from west to east [Nakano, 1981; Ishizuka, 1981; Miyashita, 1983]. Throughout the zone, the foliation is vertical, except in narrow en échelon zones where it flattens toward the west. A conspicuous horizontal stretching lineation, with consistent evidence of synmetamorphic right-lateral shear, is observed everywhere. Evidence of Miocene right-lateral ductile shear was also reported by Watanabe and Iwata [1985] and Watanabe [1988] in the northern Hidaka Belt and also by Uda [1973; 1976] in the southern part of the belt.

Jolivet and Huchon [1989] concluded that the entire Hokkaido Central Belt was a crustal-scale, transpressive, flower structure (a positive flower structure in the sense of Harding 1985] with a narrow $(10 \mathrm{~km})$, deep, ductile, strike-slip shear zone and a wide, shallower domain of en échelon thrusts and folds during the Oligocene to Middle Miocene .

\section{East Coast of the Japan Sea}

Oligocene to Middle Miocene tuffs and lavas (Green Tuffs, Ingle [1975]; Ganzawa [1982; 1983; 1987]; Iijima et al., [1988]) are widely exposed along the eastern margin of the Japan Sea and record a deformation contemporaneous with the opening. From Rebun Island to Sado Island (Figures 3 and 4), the Oligocene to Middle Miocene horizontal maximum
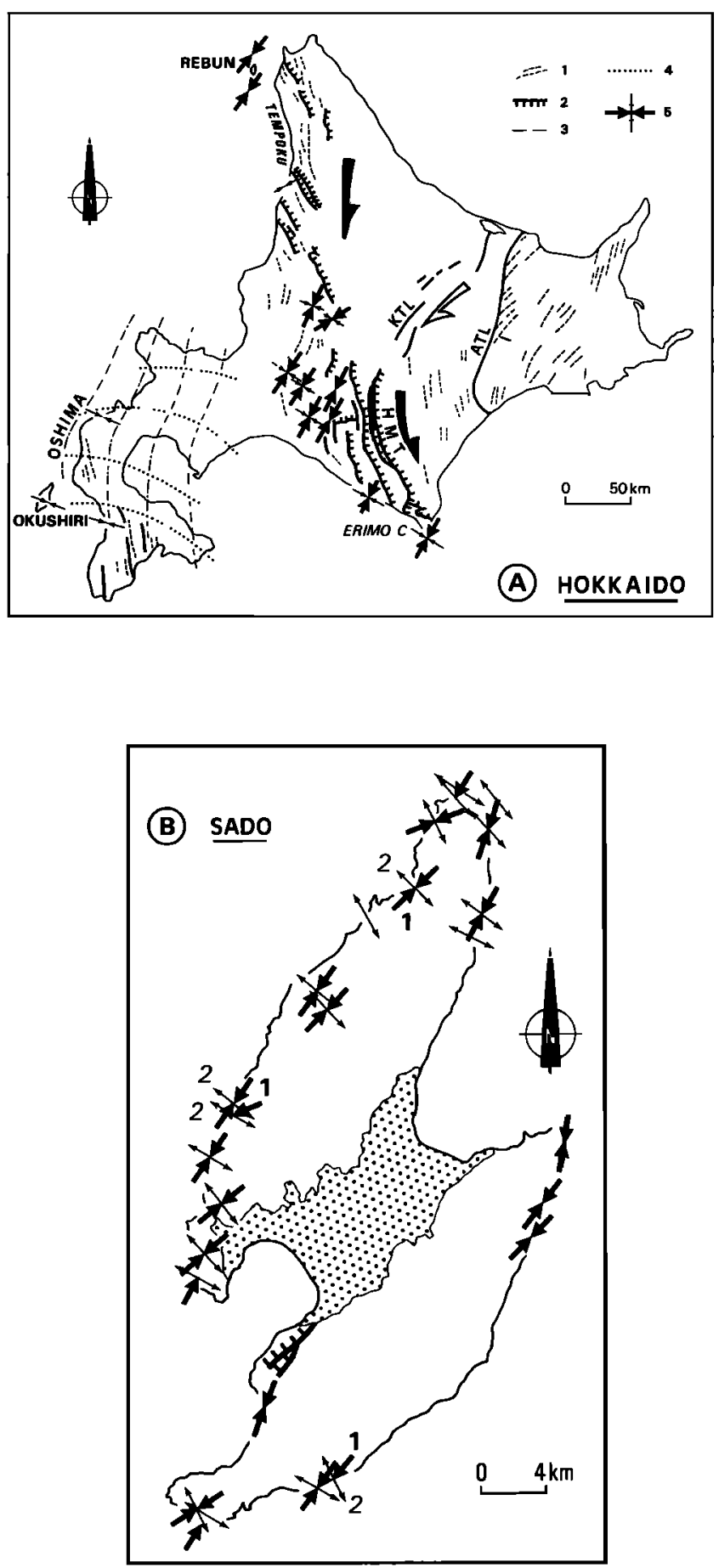

Fig. 4. Directions of the main horizontal stresses deduced from fault sets analysis in Hokkaido and Sado. 1, strike of folds axes. Key shows (2) main thrusts, (3) direction of maximum compression [after Yamagishi and Watanabe , 1986] in the Oshima peninsula, (4) direction of minimum compression after the same authors, (5) our own data, large arrows for the main horizontal compression, narrow ones for the other main horizontal stress, compressional in (a) Hokkaido, extensional in (b) Sado. Large numbers (1 and 2) refer to the successive stages recorded in Sado when these have been clearly differentiated. The open arrow along the KTL represents the right-lateral motion active after the end of Middle Miocene. ATL is Abashiri Tectonic Line, KTL is Kamishiyubetsu Tectonic Line, HMT is Hidaka Main Thrust. 
compressive stress $\left(\sigma_{H \max }\right)$, deduced from the analysis of faults sets, trends NE-SW. However, this stress corresponds to the maximum compressive stress $\sigma_{1}$ in the north where the stress regime is transpressive, while it corresponds to the intermediate stress $\sigma_{2}$ in the south, where the stress field is transtensive. In the north, thrusts faults and strike-slip faults are associated with folds, whereas in the south normal faults and strike-slip faults coexist. There is a clear transition from right-lateral transpression to right-lateral transtension from north to south.

Figure $4 b$ shows a summary of the data from Sado Island. This island is divided in two by a graben. This is one of many grabens which are now below sea level along the eastern margin of the Japan Sea. The tectonic data on this extensional deformation shed light on the evolution of the entire margin. The deformation shown in Figure $4 b$ does not affect the Late Miocene deposits which postdate the formation of the graben. The outcrops show the association of strike-slip and normal faults and the principal horizontal compressive stress consistently strikes NE-SW. Although the stratigraphic data are not precise enough to conclude two discrete stages, we observed at many outcrops the succession from a strike-slip movement to a normal movement with a strike-slip component. In some cases, the earlier strike-slip faults crosscut flat-lying reverse faults compatible with the same direction of $\sigma H \max$. It seems that the deformation mechanism was first transpressive then transtensive with a larger component of extension with time.

In the Oga peninsula the direction of $\sigma H \max$ was determined from a dyke swarm. We observed in several places right-lateral en échelon relationships between dykes as well as reverse faults giving the direction of $\sigma_{1}$ along the $N 30^{\circ}$ to $50^{\circ} \mathrm{E}$ direction. These dykes were thus not emplaced in an extensional stress field but in a right-lateral transpressive one.

Further to the south, the Cenozoic deformation is concentrated along the Cretaceous Nihonkoku-Miomote shear zone described by Otsuki and Ehiro [1978]. Like other leftlateral Cretaceous shear zones (Tanakura tectonic line) it is reactivated as right-lateral during the Cenozoic [Koshiya, 1986]. Along the coast, the basement of the Cenozoic deposits (Cretaceous granites) is cut by flat-lying normal faults compatible with the same transtensional stress field as in Sado Island.

\section{Analysis of the Bathymetric Features along} the Eastern Margin of the Japan Sea

Tamaki and Honza [1985], Okada et al. [1985], and Lallemand et al.[1985] showed that the Shiribeshi trough, Okushiri basin, and Nishi-Tsugaru basin (Figures 3 and 5), presently active as compressional structures, are reactivated extensional structures. Their en échelon relations, and the tectonic history of Sado Island favor a right-lateral shear zone along the eastem margin from Oligocene to Middle Miocene.

A simple analysis of the bathymetric chart of the eastem margin [Maritime Safety Agency of Japan, 1980a;b] which is reproduced in Figure 3 reveals that two directions of scarps prevail: (1) the direction of the grabens and (2) the direction of linear structures trending NNW-SSE to N-S. Figure 5 gives an interpretation of these structures. The NNW-SSE trending structures correspond to right-lateral transfer faults between the grabens. We shall consider later the implication of the progressive change in strike from north to south for the transfer faults.

\section{A Right-Lateral Shear Zone}

The first observation is the consistency in the strike of $\sigma_{H \max }$ from north to south (N30 ${ }^{\circ} \mathrm{E}$ as an average) based on the analysis of fault sets as we have shown in a previous section.
This is in good agreement with the results of Otsuki [1989] in NE Honshu, based on the directions of dykes and metalliferous veins.

The second observation is that this deformation corresponds to right-lateral transpression to the north coeval with the deformation of the Hidaka Shear Zone, and to right-lateral transtension to the south. This spatial evolution is also observed in time on Sado Island although more precise stratigraphic data would be needed to confirm this theory. The third observation is that the Cretaceous left-lateral shear zones such as the Nihonkoku-Miomote and Tanakura tectonic line are reactivated as right-lateral faults during the Tertiary. The fourth observation is that this right-lateral shear ended before the Late Miocene. All these characteristics are compatible with the environment of the margin of a right-lateral pull-apart basin settled onto a pre-faulted continental basement.

The northem extension of this system can be followed in Sakhalin (Figure 1; Rozhdestvenskiy, 1982; 1986; Kimura et al., 1983] as a well developed dextral strike-slip system along the Okhotsk-Amur plate boundary. Deep narrow basins of the Tartary strait west of Sakhalin [Antipov et al., 1980] have probably been formed in this strike-slip environment. From Hokkaido and northward the right-lateral shear zone is located between two continental blocks. The deformation along this intracontinental boundary is transpressional. South of Hokkaido the strike-slip shear zone is in a backarc position. During the Early and Middle Miocene the Japan arc faced only the Pacific plate, the Philippine Sea Plate being far to the south [Jolivet et al., 1989]. This transition from an intracontinental compressional context to a back-arc setting explains the transition from transpression to transtension from $N$ to $S$.

\section{Review of the Tectonic Data on the Western Margin of the Japan Sea}

Sillitoe [1977] quantified the amount of right-lateral displacement along the Yangsan-Tsushima faults. These two faults run NNE-SSW along the eastern coast of Korea and in the Tsushima strait. Sillitoe noticed that one can correlate metallogenic belts in the Korean peninsula and SW Japan if one considers a right-lateral offset of $200 \mathrm{~km}$ (Figure 2). The displacement was achieved during Oligo-Miocene time after the formation of the youngest belt at $42 \mathrm{Ma}$ and before the recent left-lateral motion along the Tsushima fault. This recent motion gives rise to left-lateral en échelon compressive structures affecting Tertiary sediments in Tsushima island. Counterclockwise local rotations shown by paleomagnetism [Ishikawa and Torii, 1988] occurred after the intrusion of a 14 Ma pluton.

The right-lateral motion is also seen in South Korea by en échelon NE-SW trending normal faults in the Miocene deposits of the Pohang basin. Basaltic lavas were extruded during Early Miocene along these NE trending tension gashes [Lee and Pouclet, 1988]. These en echelon normal faults are located east to the NNE-SSW trending Yangsan fault. We can also interpret this simple geometry as the result of a right-lateral shear along the Yangsan fault.

The age of the right-lateral motion is thus bracketed between 42 and $14 \mathrm{Ma}$. It may have stopped slightly earlier than along the eastern margin of the Japan Sea. The clockwise rotations shown by McCabe et al. [1988] in Early Miocene deposits east of the Yangsan fault in South Korea also favor a right-lateral motion along this fault during Miocene time.

Several workers [Murata, 1987; Fabbri et al., 1987] attempted to relate the obvious bending of the pre-Cenozoic belts of SW Japan in Kyushu with the clockwise rotation deduced from paleomagnetic measurements. They showed that 


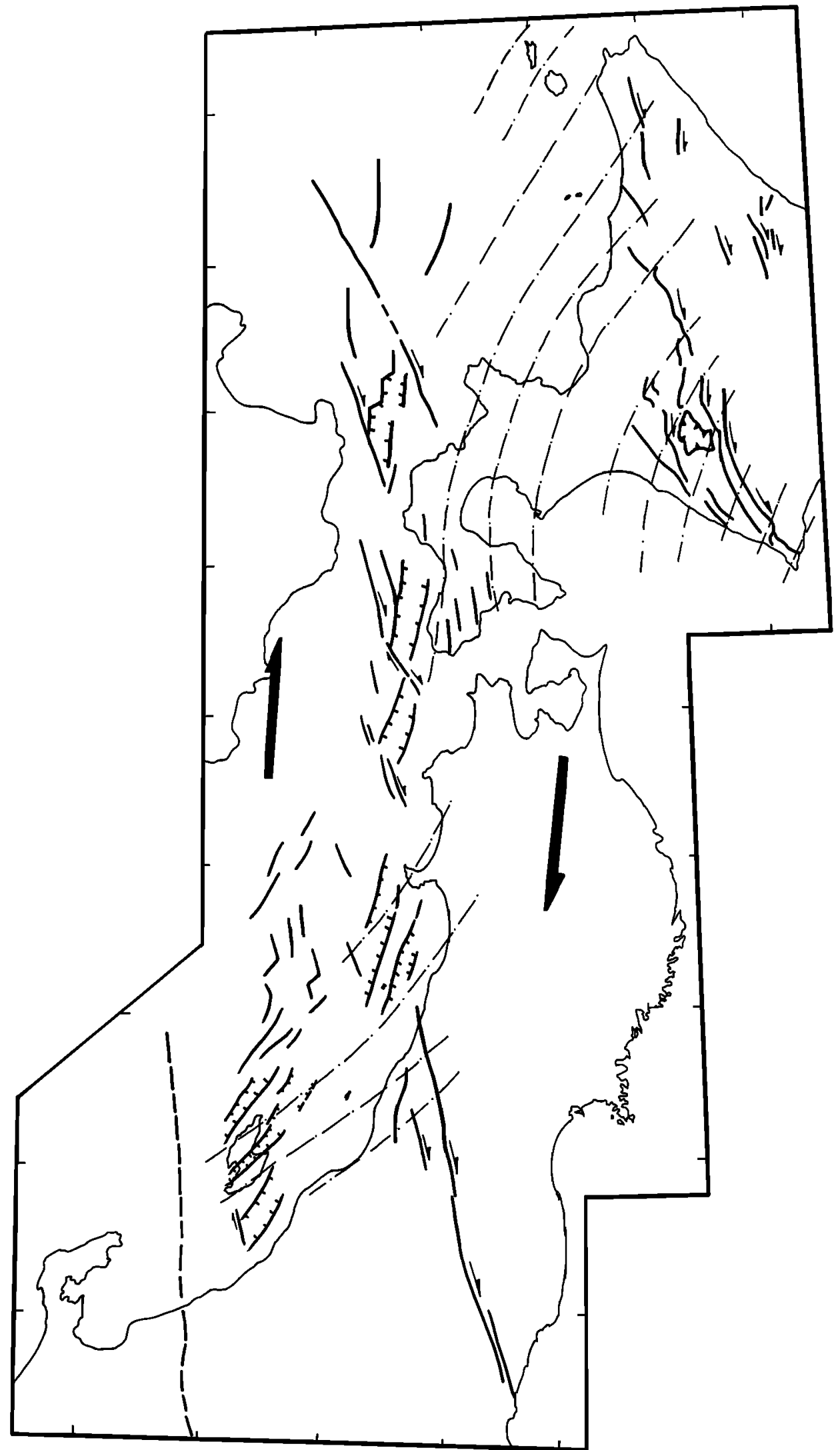

Fig. 5. Tectonic interpretation of Figure 3. Dashed curves, direction of $\sigma_{H \text { max }}$; small arrows; motion on individual faults; large arrows, resultant motion on the major shear zone. 
the bending also affects the Eocene structures. They described conical folds with steeply dipping axes, on the concave side of the bending (southeastem Kyushu), and Miocene grabens radially disposed on the convex side (northem Kyushu on the Japan Sea side, Figure 2). This supports the idea of a Miocene age for the bending.

\section{Conclusion}

The offshore and onland tectonic data along the eastern and western margins of the Japan Sea are compatible with a rightlateral pull-apart opening (Figure 6) during Oligocene-Middle Miocene time, followed in Late Miocene by the E-W compression, still active at present time.

The opening was also accompanied by a rotation of SW Japan possibly about a pole located in the Tsushima strait and the consequent bending of the arc. Rotations about vertical axes associated with strike-slip faults are already well known [e.g. Ron et al., 1984; Walcott, 1984; 1987; Hornafius et al., 1986; Jackson, 1987; Lamb, 1988].

Is then the right-lateral pull-apart opening mechanically compatible with the clockwise rotation of SW Japan? The following is an attempt to answer this question using smallscale experiments.

\section{SMAL-SCale ANALOG ExPERIMENTS}

We have performed the small-scale experiments presented in the following section to examine the kinematic and mechanical compatibility of clockwise block rotations with right-lateral pull-apart opening and to determine which type of boundary conditions favor this development.

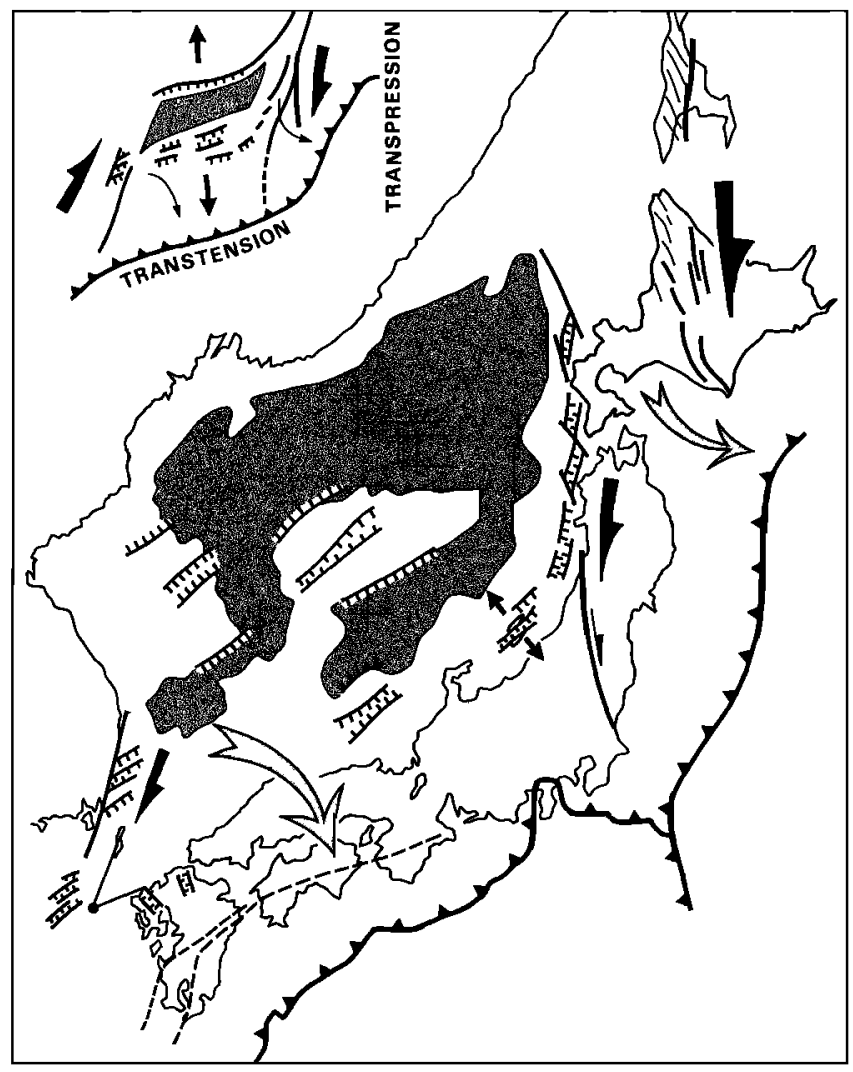

Fig. 6. Simplified opening model with right-lateral pull-apart and dextral rotations in the transtensional domain and sinistral rotations in the transpressional one. Large solid arrows: motion on the major shear zones; divergent arrows: direction of extension; curved arrows: component of block rotation.

\section{Experimental Procedure}

We used the small-scale modeling technique of a brittleductile system described by Faugère and Brun [1984], and Vendeville et al. [1987]. The two-layer models are made of Fontainebleau sand representing the upper brittle crust and silicone (Rhodorsil Rhone Poulenc) representing the lower ductile crust. The layers are added to a rectangular container, the base of which is made of a fixed plate and a mobile one (Figure 7). The mobile plate, which is displaced at a constant velocity, has a "dog leg" shaped boundary, which applies pure strikeslip and transtensional displacements to the base of the silicone.

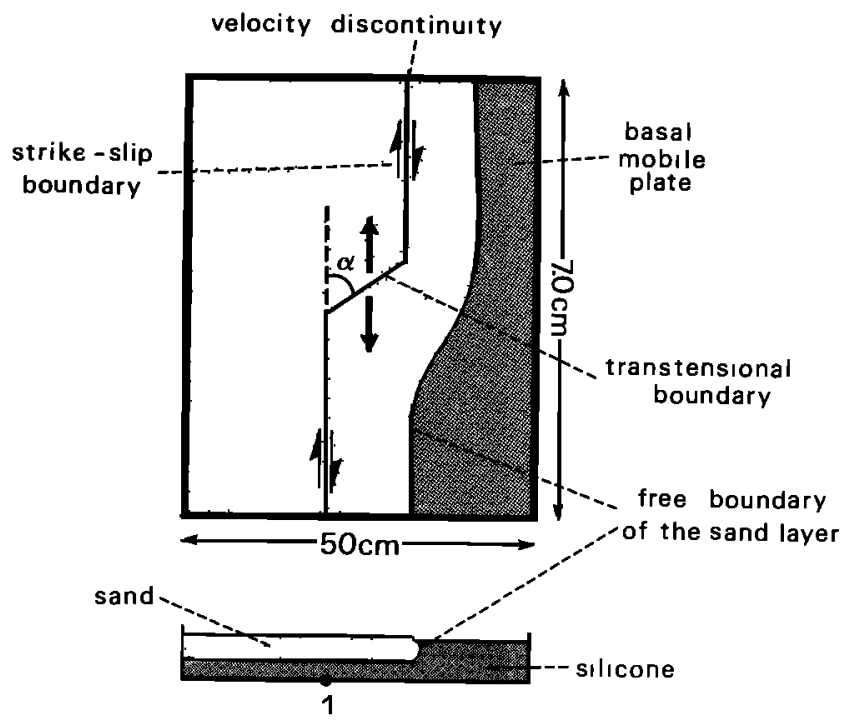

Fig. 7. Schematic description of the small-scale experiments (1 shows velocity discontinuity).

Models are scaled to fit the shear strength profile of the continental crust [Goetze and Evans, 1979]. The sand yields by a Mohr-Coulomb criterion with an internal frictional angle of $30^{\circ}$, which may satisfactorily model the frictional behavior of the upper crust [Byerle., 1978]. The silicone putty has a viscosity of $10^{4} \mathrm{~Pa} . s$ at room temperature. Its shear strength depends on displacement velocities. In the experiments presented here, sand and silicone layers have a thickness of 1 $\mathrm{cm}$. For such a model an appropriate shear strength for the silicone layer is obtained for velocities varying between 0.5 and $10 \mathrm{~cm} / \mathrm{h}$ (i.e., weak and strong viscous coupling).

Before $12 \mathrm{Ma}$ (i.e. before the beginning of the E-W compression), the Pacific subduction could be considered a stress-free boundary (totally free of stress or partly extensional if slab-pull is active) during the Japan Sea opening. To test the consequences of this lateral boundary condition, most of the models were constructed such that the sand did not reach the right wall of the container. Free space between the model and the lateral wall was filled with silicone. The shape of the free boundary is built identical to that of the basal mobile plate to maintain a constant distance between them. During the building of the sand layer, sand loading creates a flow of the material toward the free space. Even a small amplitude flow near the free boundary is sufficient to create grabens (see Figure 10 ), so that, strictly speaking, the eastern boundary is not free of stress but subjected to extension.

Twelve experiments with various displacement velocities and with or without a stress-free lateral boundary have been conducted. Only a few of them are reported here; a more detailed 


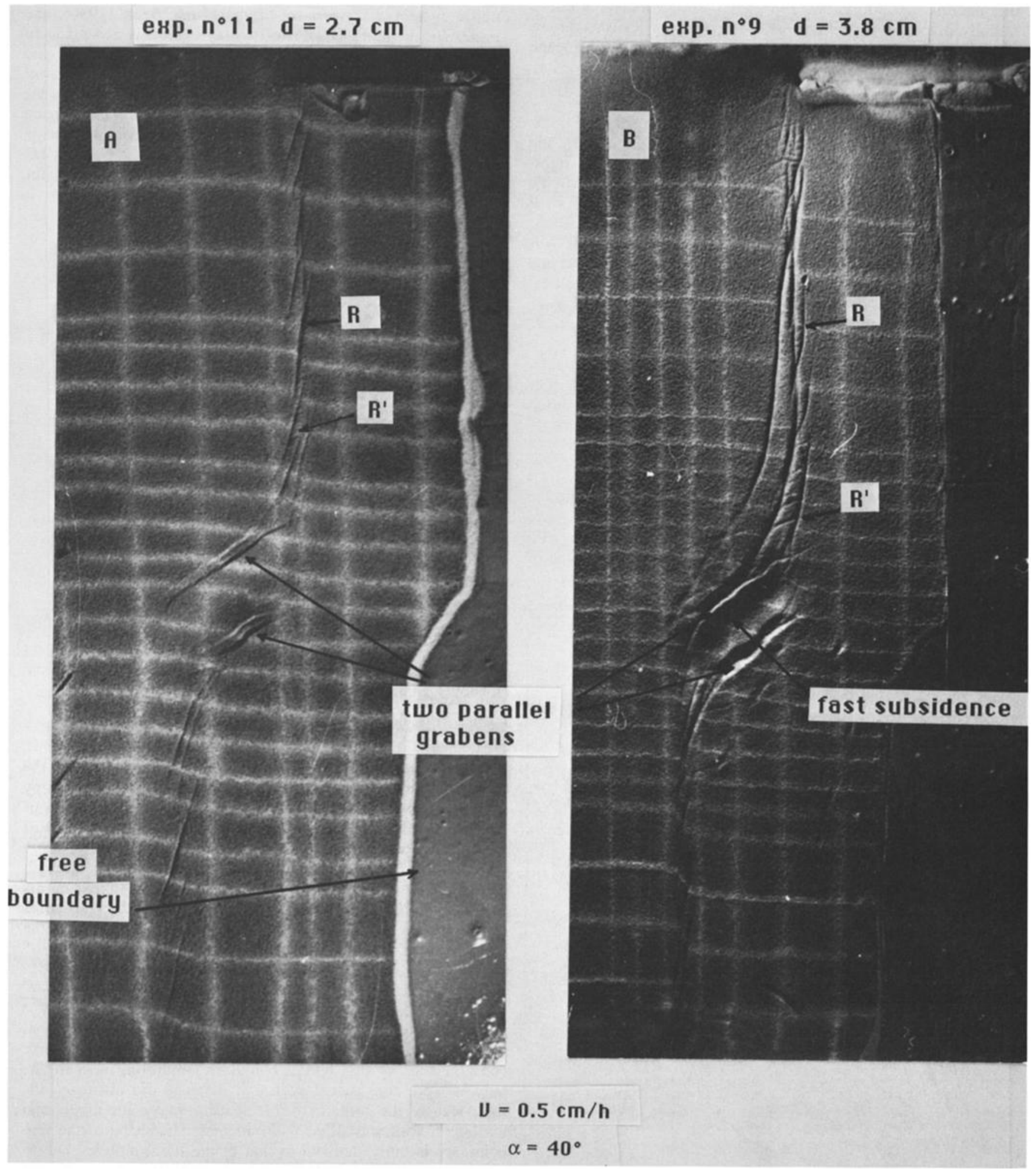

Fig. 8. Experiments $9(a)$ and $11(b)$ show the fault pattern with a small displacement and low velocity (O.5 $\mathrm{cm} / \mathrm{h})$ and $\alpha=40^{\circ}$. Displacement are shown by the deformation of the white grid, originaly equally spaced (2.5 $\mathrm{cm}$ at the center of the model where most of the deformation occurs, $5 \mathrm{~cm}$ elsewhere). At higher velocities the fault pattern is similar at the beginning of the displacement. Note the $R$ and $R^{\prime}$ Riedel shears and the two parallel grabens in the transtensional area which define a quickly subsiding and rotating block. 
report will be published later. In the following we describe the general characteristics, similarities and differences of the experiments.

\section{Fault Pattern}

The fault pattern which develops at the onset of deformation combines strike-slip faults above the basal strike-slip boundaries and oblique normal faults above the transtensional boundary. This is well shown by experiments 9 and 11 in Figure 8 with an angle of $40^{\circ}$, displacement velocities of 0.5 $\mathrm{cm} / \mathrm{h}$, and bulk displacements of 3.8 and $2.7 \mathrm{~cm}$. The transtensional domain is characterized by a large amplitude depression bounded by two parallel grabens. The set of strikeslip faults exhibits well-developed en échelon shear, slightly oblique to the main fault direction ( $R$ type Riedel shear). In the proximity of the transtensional area the faults curve and antithetic $R^{\prime}$ type Riedel shears develop. This defines dominotype systems. This general pattern is similar to the one obtained in Mandl's [1987] experiments. At the junction of the transtensional and strike-slip domains the Riedel shears tend to connect with the grabens.

The angle of grabens on the strike-slip boundary increases with $\alpha$ (see Figure $9 a$ where $\alpha=90^{\circ}$ ). Note also that in this case Riedel shears pass progressively to grabens toward the transtensional area.

\section{Block Rotations}

In the central area, blocks bounded by grabens undergo a rigid dextral rotation during the displacement (Figure $8 a$ ). As the displacement increases, the distance between Riedel shears connected to the grabens at the termination of the central area increases. $R^{\prime}$ type Riedel shears develop creating a system of rotating dominos (Figure $8 b$ ). This set of experiments demonstrates that block rotations are enhanced by the existence of a free lateral boundary.

Figure 9 illustrates the progressive rotation of the central block for displacements up to $7 \mathrm{~cm}$. The bulk pattern may be compared with the Japan Sea structure where roughly N-S trending strike-slip faults are connected with NE-SW trending grabens. The central block can be compared with the Yamato bank which separates the two main basins (Japan and Yamato Basins) and suffered a strong subsidence and clockwise rotation (see below) during the opening. We show in a later section that geometrical considerations require a clockwise rotation of the Yamato Bank during the opening. In any case, the rotation must have occurred before $14 \mathrm{Ma}$ [Sayanagi et al., 1987]. The $30^{\circ}$ of dextral rotation of SW Japan also fits this model well. Note that the amount of block rotation in the transtensional domain increases with $\alpha$.

Figure 10 illustrates the development of a domino system (also active in Figure 9, but less clear). From the beginning of

$$
\alpha=90^{\circ} \quad V=3 \mathrm{~cm} / \mathrm{h}
$$

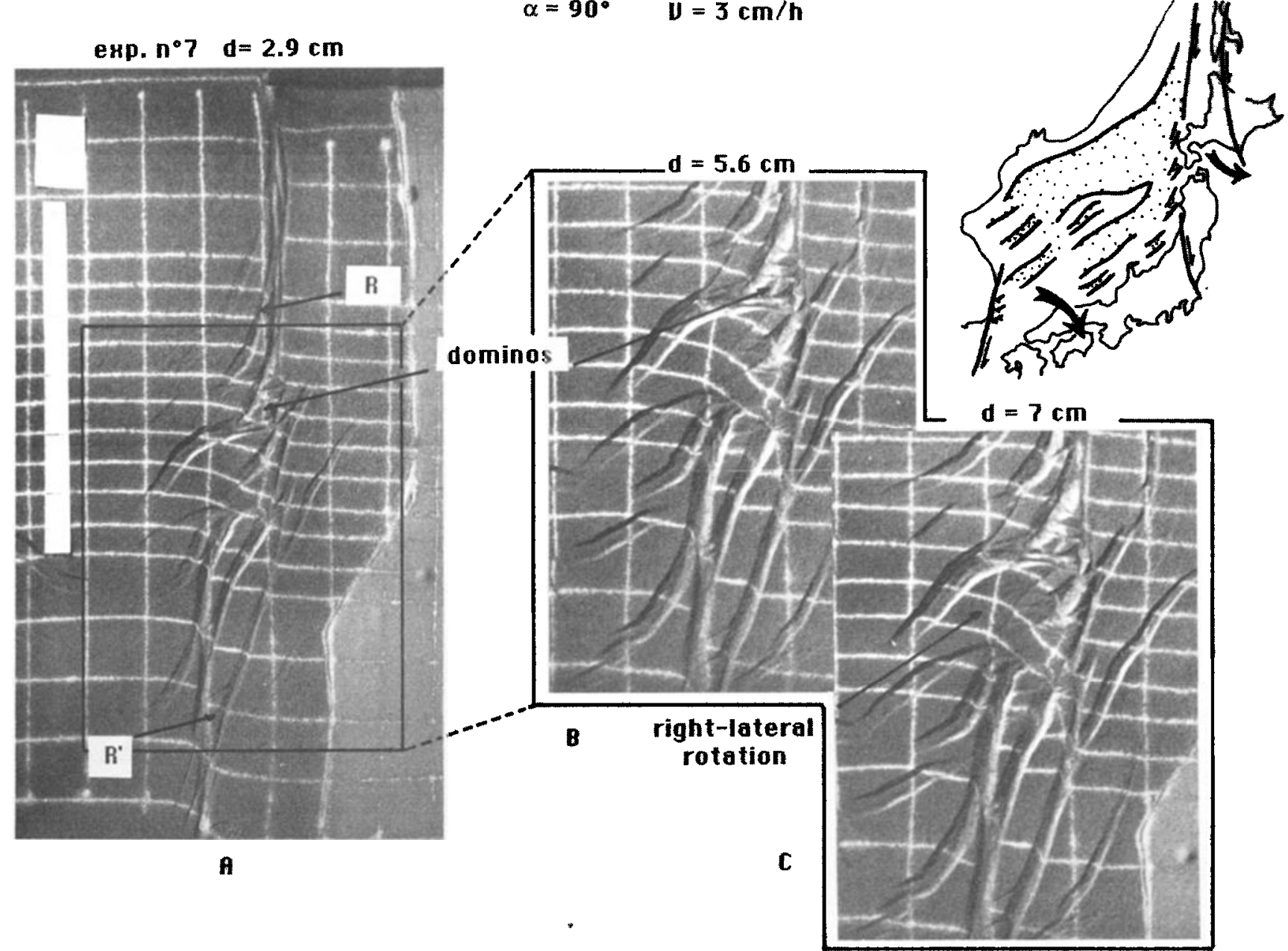

Fig. 9. (a) Experiment 7 with $\alpha=90^{\circ}$, and velocity $=3 \mathrm{~cm} / \mathrm{h}$. Center of the model after (b) 5.6 and (c) $7 \mathrm{~cm}$ of displacement. Note the domino system and the clockwise rotation of the central block. A simplified sketch of the structure of the Japan Sea illustrates the comparison which is made in the text. 


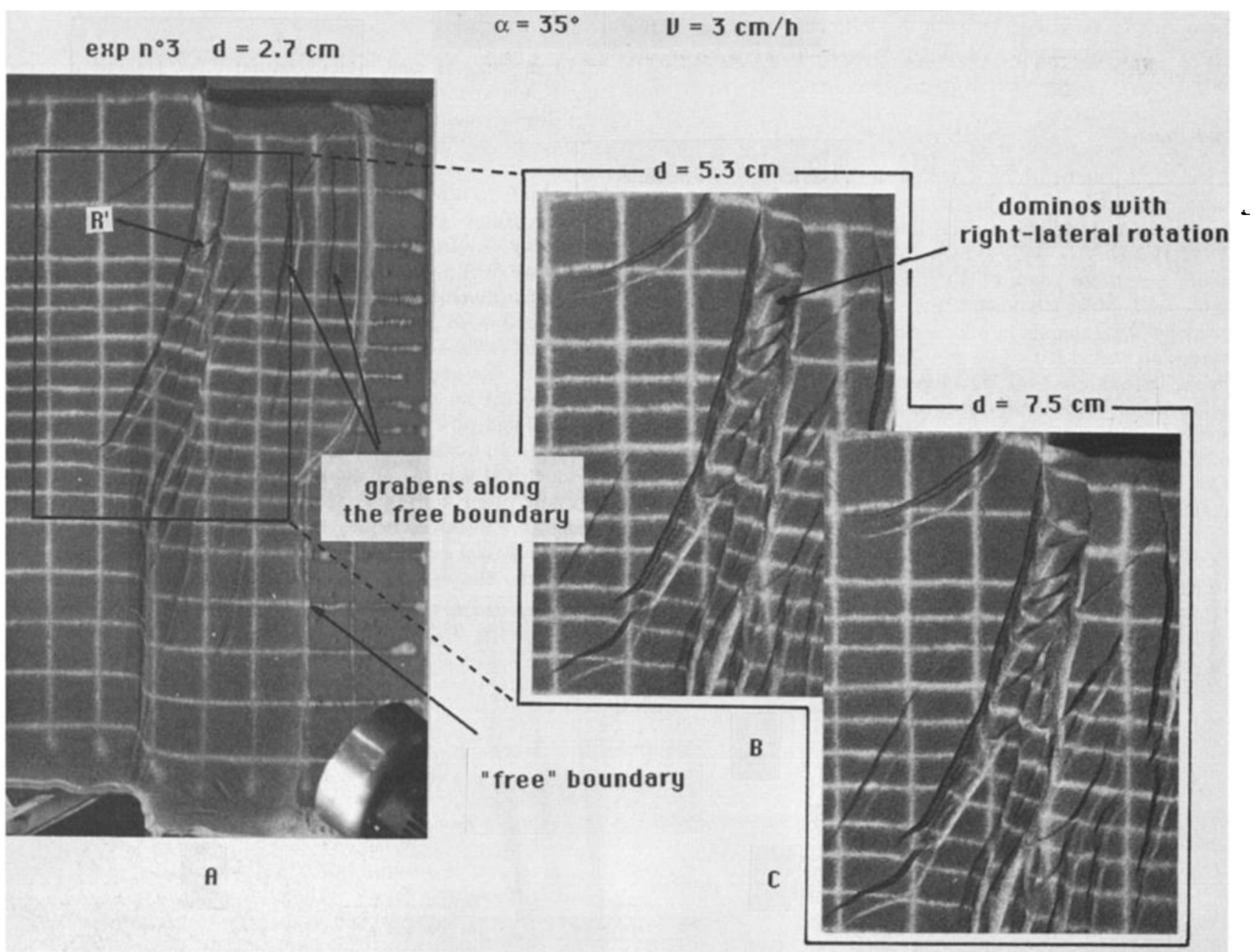

Fig. 10. Experiment 3 with $\alpha=35^{\circ}$ and velocity $=3 \mathrm{~cm} / \mathrm{h}$. It shows very clearly the development of the domino system. Note that the rotation of dominos is accomodated by letft-lateral motion along $R^{\prime}$ shears and that during the rotation the width of the domino system increases. Note also the grabens which develop along the free boundary. Displacement (a) $2.7 \mathrm{~cm}$, (b) $5.3 \mathrm{~cm}$, (c) $7.5 \mathrm{~cm}$ is shown.

the deformation, $\boldsymbol{R}$ Riedel shears of the strike-slip domain pass to oblique normal faults in the transtensional domain (Figure $10 a)$. As the displacement increases, they separate and $R^{\prime}$ leftlateral shears develop between them (Figures $10 a$ and $10 b$ ). Subsequent deformation rotates the fault-bounded blocks like dominos. Figures $10 b$ and $10 c$ show that block rotation decreases and disappears where $R^{\prime}$ shears are not present. A direct comparison beween these models and the Japan area suggests the occurrence of dextral rotating domino systems along the eastern margin of the Japan Sea. The "en échelon" grabens which exist in this region could be interpreted in this way.

This deformation pattem with rotation of dominos has been studied by Nur et al. [1986] and Mandl [1987]. Martell et al.[1988] and Ron et al. [1984] described field examples of such structures. Martell et al. [1988] explained that the rotation sense of blocks bounded by cross faults between two sinistral boundary faults is determined by the component of movement across these boundary faults: if an extensional component is present the sense of rotation is counterclockwise, if a component of compression is instead present the sense of rotation is clockwise. In Nur et al. [1986] the authors concluded to a rotation in the opposite sense but predetermined the crossfaults in a position which does not correspond to what we observe here. In our experiments the distance between the two boundary faults increases during the rotation. This is allowed by the extensional component introduced by the free boundary.

Although the comparison of the models with the opening of the Japan Sea (Figure 9, insert) is interesting, the $20^{\circ}$ of sinistral rotation in northern Japan deduced from paleomagnetic data and also from our reconstructions (see below) still has to be explained. One solution is that the reverse sense of rotation here is related to the dextral transpressive motion which characterized the northern part of the basin.

\section{RECONSTRUCTIONS}

The reconstructions are made using constraints from the structural and paleomagnetic data and the asymmetric pull-apart mechanism (with a "free boundary") just discussed. The rotations of the different blocks and the right-lateral displacements are constrained by the present structure of the basin.

Figure 11 shows the right-lateral transfer faults between the en échelon grabens along the eastern margin of the Japan Sea. The strikes of these faults progressively change from NW-SE in the north to N-S in the south. Figures 11 and $12 a$ show that these trends fit small circles about a pole located at $35.8^{\circ} \mathrm{N}$ and $122^{\circ} \mathrm{E}$ which also fits the Tsushima fault. Thus the deformation 


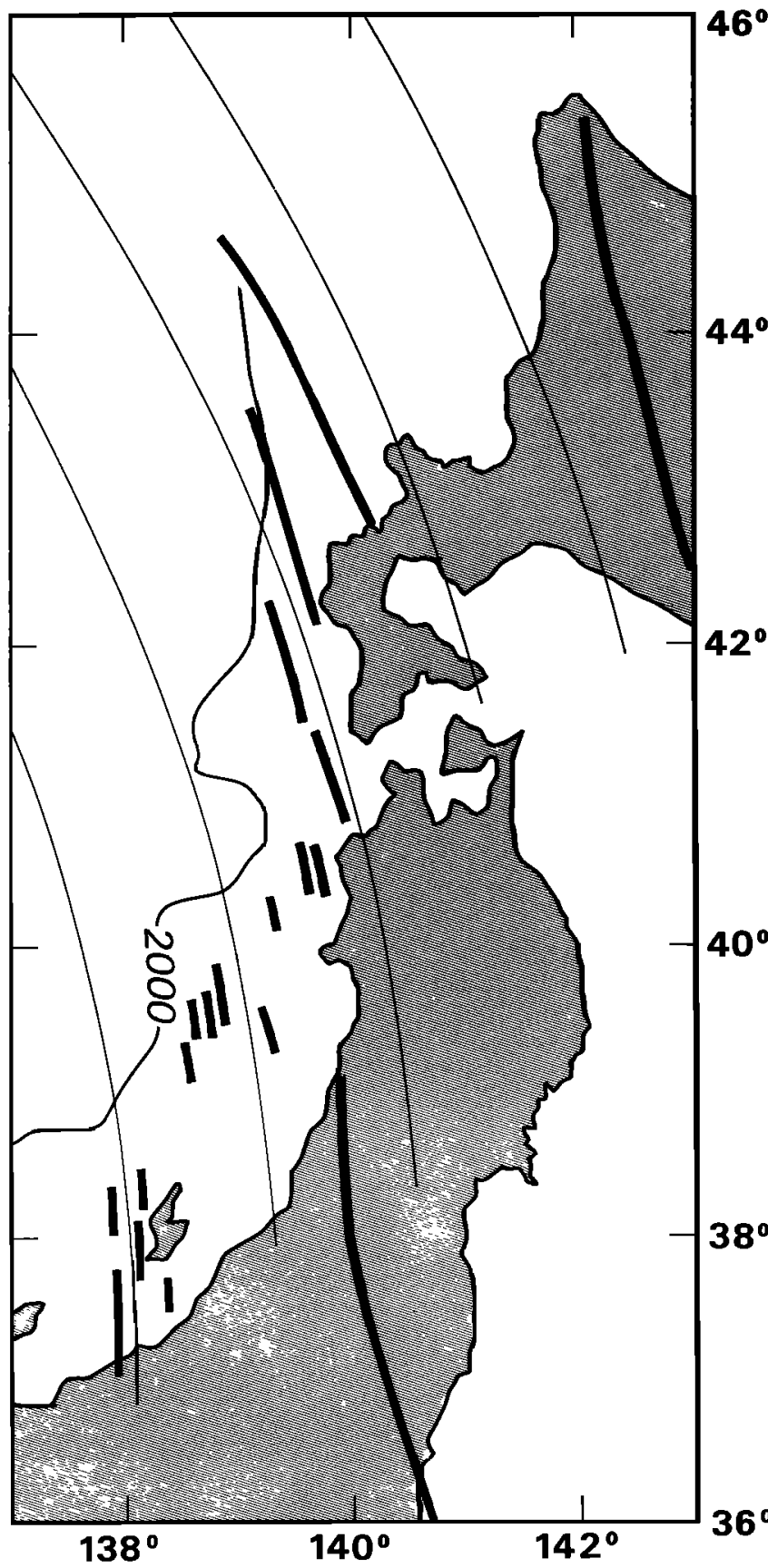

Fig. 11. The transfer faults recognized in Figure 3 and 5 (thick lines) fit small circles about a pole located at $35.8^{\circ} \mathrm{N}$ and $122^{\circ} \mathrm{E}$.

is distributed over the whole width of the dextral shear zone with a single rotation pole.

We reconstruct the position of the Yamato Bank before the opening taking into account the shape similarity between its northem margin and the corresponding area of the Eurasian margin. A fit of these two features gives a pole located at $34^{\circ} \mathrm{N}$ and $129^{\circ} \mathrm{E}$ which is very close to the pole of the rotation of SW Japan proposed by Otofuji and Matsuda [1983].

To accommodate the deformation observed along the Hokkaido Central Belt, one must consider a certain amount of shortening during the strike-slip movement. Given the direction of the belt, one needs a pole that makes the Okhotsk block move along a roughly north-south direction. Thus the pole is rather remote. We finally end with three different rotation poles to move the various blocks. The more external the block the more remote the pole. The rotation pole of the block located between the two master strike-slip faults (southwestem Japan) is closer than than the pole of the outside block (northeastem Japan). The crustal structure recognized by Tamaki [1986] (Figure 2] in the Japan Sea constrains the total amount of rotation we can use. Figures $12 b$ and $12 c$ show two reconstructions. Figure $12 b$ corresponds to the hypothesis of a single stage opening. The analog experiments show that the simultaneous opening of two depressions (Japan basin and Yamato Basin) with a rotating unstrained block between (Yamato bank) is possible. Figure $12 c$ is a possible preopening reconstruction. The total clockwise rotation of $S W$ Japan is $20^{\circ}$. The total counterclockwise rotation of NE Japan is also $20^{\circ}$.

The history of the opening can be summarized as follows (Figure 12d) from Late Oligocene to Middle Miocene (further data are needed to constrain more precisely the timing): a rightlateral shear was distributed over the whole Japan Arc and Sakhalin region with a transtensional context in the south and a transpressional one in the north. This led to the formation of NE-SW pull-apart basins in the Japan Sea region. The two main grabens evolved and became oceanic basins giving birth to the Yamato and Japan Basins. Within this wide dextral shear zone, tectonic blocks rotated about vertical axes during the basins opening. During this process all the earlier major Mesozoic faults were reactivated. The strike-slip motion stopped about $12 \mathrm{Ma}$ ago and was replaced by an E-W shortening which is now localized along the eastem margin as an active zone of underthrusting.

\section{Conclusion}

We model the Japan Sea opening as a distributed dextral shear over a width of about $500 \mathrm{~km}$ from $E$ to $W$. The deformation proceeds along two N-S trending boundary shear zones with rotations of blocks between them. The finite displacement of the eastern margin relative to the western one is comparable to the overall size of the basin $(500 \mathrm{~km})$.

The deformation of the island arc has been complex. The marginal basin opened in a dextral shear context with a component of extension along the Pacific margin. Only the northern part of the system (Hokkaido Central Belt and Sakhalin) has been subjected to a transpressive stress field leading to counterclockwise rotations there. The reconstructions shown here are described in terms of rigid blocks rotations although a more complex model with distributed deformation is more likely.

Distributed deformation across the $80-\mathrm{km}$-wide area along the New Zealand Alpine fault has been demonstrated by Walcott [1984;,1987], Jackson [1987], Lamb [1988] on the basis of a geodetic and paleomagnetic survey. Hamburger and Isacks [1988] have intepreted the opening of the North Fiji basin as a mega pull-apart along the Pacific-Australia plate boundary. West of the Japan Sea, the Bohai intracontinental basin also opened in a dextral shear zone [Nabelek et al., 1987; Chen and Nabelek, 1988]. The opening of such basins can no longer be considered to be only caused by trench retreat which may provide the overall transtensional stress field but not the strike-slip component. The continental collision of India and Asia is the most likely candidate as a driving phenomenon for these major N-S dextral faults. Tapponnier et al .[1982, 1986] emphasized the role played by left-lateral motion along the Red River Fault in the South China Sea opening in the Late Tertiary. Kimura and Tamaki [1986] first proposed that the right-lateral pull-apart opening of the Japan Sea is a consequence of the India-Asia collision. Based on small-scale 


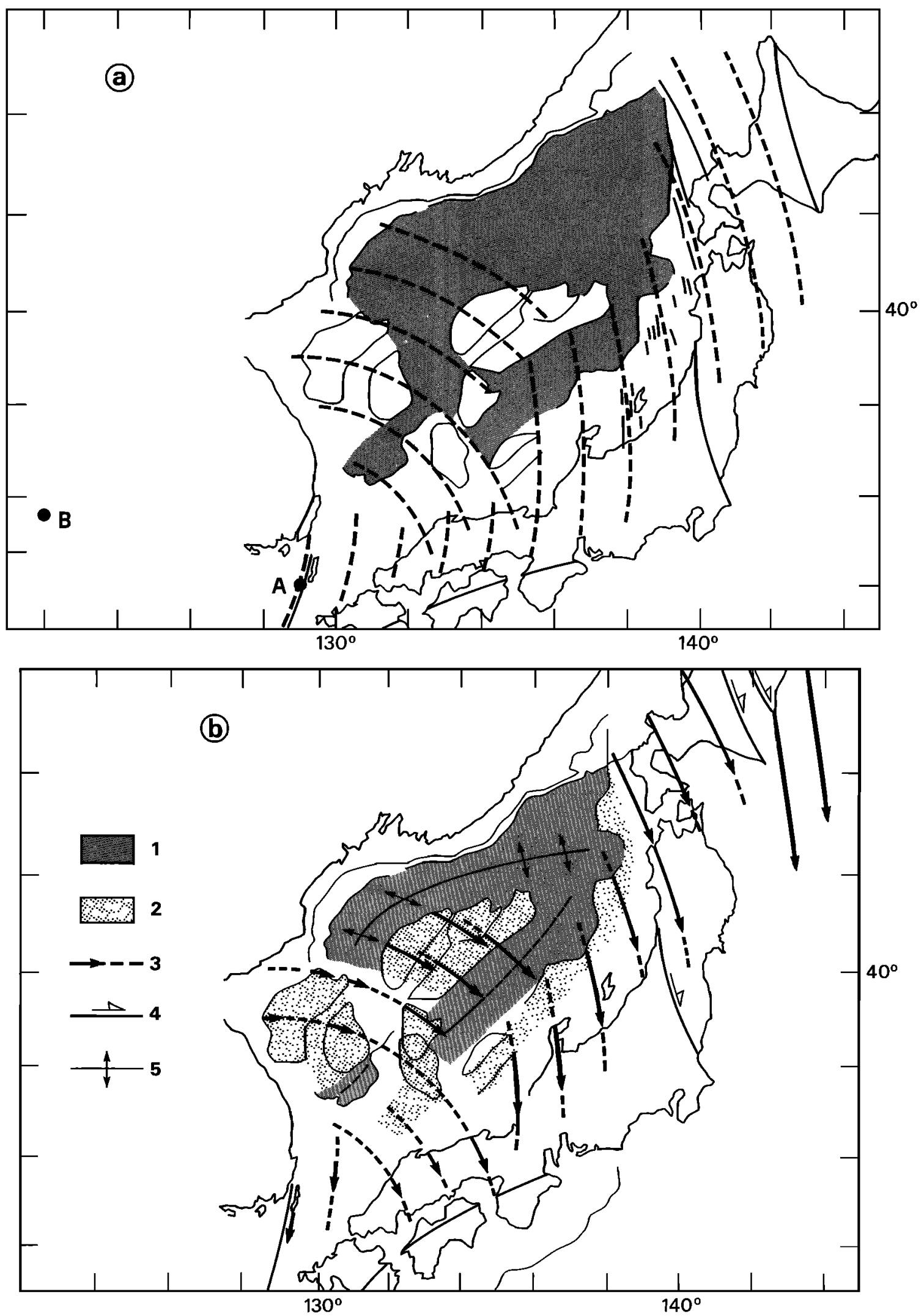

Fig. 12. Kinematic model and reconstructions of the Japan Sea opening. (a) Present stage and the small circles about the poles used in the reconstructions (A: $34^{\circ} \mathrm{N}, 129^{\circ} \mathrm{E}$, which is used for the rotation of SW Japan and the Yamato Bank inside the pull apart system, B: $35.8,122^{\circ} \mathrm{E}$, used for the southward drift due to the right-lateral pull-apart). (b) Reconstruction during the opening assuming that the Japan basin and Yamato Basins opened almost synchroneously. The arrows represent the displacement vectors necessary to reach the present day position, the dashed curves stand for small circles. Key shows (1) oceanic crust, (2) thinned continental crust, (3) small circles, (4) main strike-slip faults, (5) spreading centers. (c) Possible configuration at the beginning of the opening according to our model. (d) Synthetic figure showing the north-south translation and progressive bending of the arc. Dark shading represents the present-day situation, light shading is the preopening situation, and the intermediate shading represents a stage during the opening, possibly around $20 \mathrm{Ma}$. 

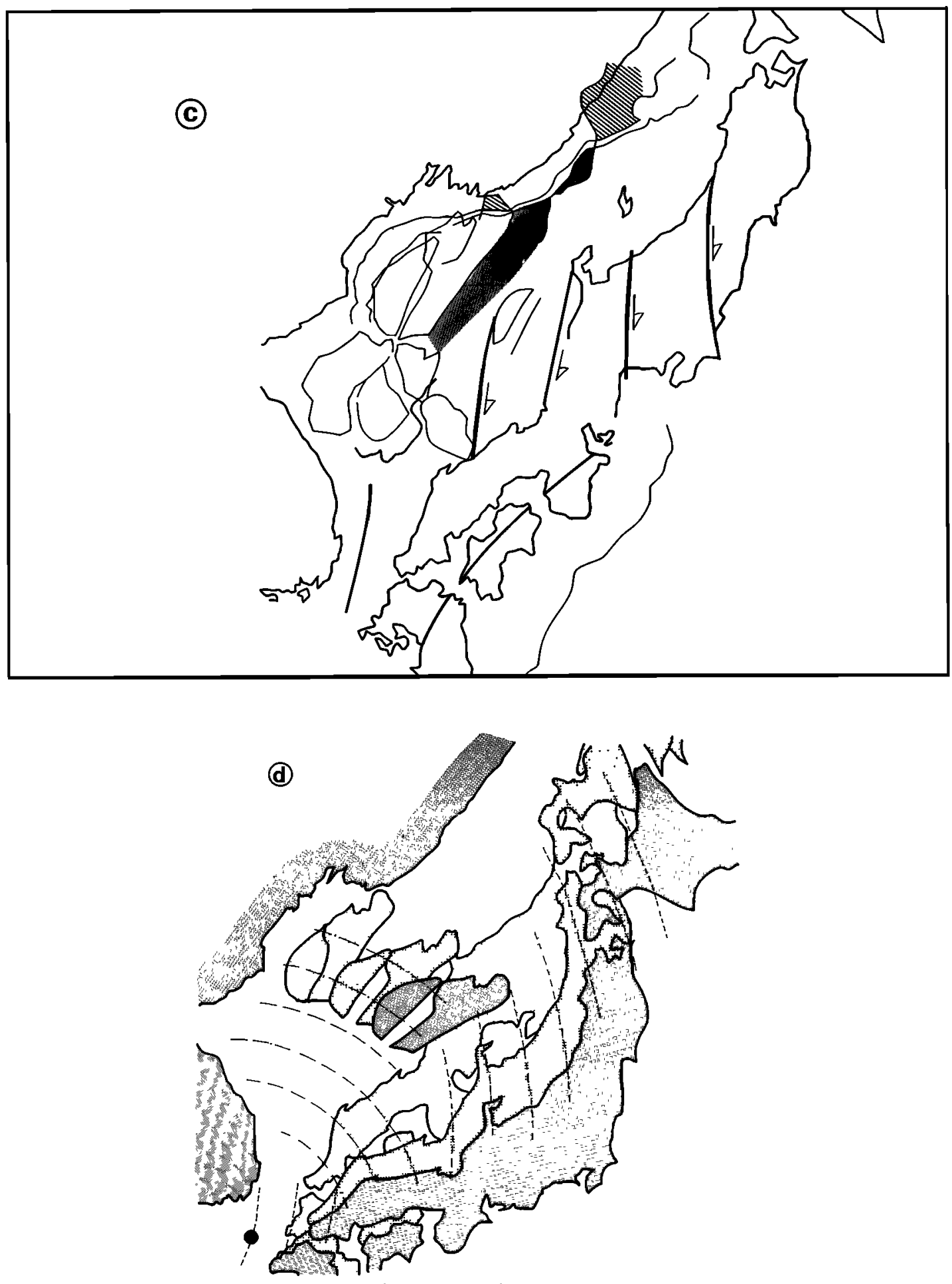

Fig. 12. (continued)

experiments of continental collision by Cobbold and Davy [1988] and Davy and Cobbold [1988], we proposed [Jolivet et $a l ., 1990]$ that the right-lateral faults in the Japan Sea and Bohai Gulf regions are N-S trending conjugates of the major NE-SW trending left-lateral faults which guide the motion of continental blocks eastward. This is, however, possible, only if the Pacific subduciton provides the low stress condition along the eastem boundary of the deforming system. The description of the geometry and mechanics of the opening made in the present paper will be used in our future works to understand the respective parts played by the Pacific subduction and the extrusion tectonics in terms of kinematics and, if possible, of forces. One important question is, for instance, the reason of the drastic change from extension to compression in Late Miocene and the resulting inception of a new subduction zone along the eastern margin of the Japan Sea in the Quatemary [Nakamura, 1983; Tamaki, 1988].

Acknowledgments. The authors are indebted to their colleagues in Japan, particularly $K$. Tamaki for fruitful 
discussion. K. Otsuki and T. Ohguchi and S. Miyashita and all the members of the Hokkaido Tectonics Research group were of considerable help for the survey in northern Honshu and Hokkaido. Thanks are due to $\mathrm{R}$. McCabe and the second anonymous reviewer, as well as to $R$. Davies for useful comments and improvement of the English. Part of this work was financed by the French Ministry of Foreign Affairs.

\section{RETERENCES}

Angelier, J., Tectonic analysis of faultslip data sets, $J$. Geophys. Res., 89, 5835-5848, 1984.

Antipov, M. P., Kovylin, V. M. and V. P. Filat'yev, Sedimentary cover of the deep water basins of Tatar strait and the northern part of the sea of Japan. Int. Geol. Rev., 22, 1327-1334, 1980.

Byerlee, J. D., Friction of rocks, Pure Appl. Geophys., 116, 615-626, 1978.

CCOP-IOC, Southwest Japan, Korea peninsula, International decade of ocean exploration ]IDOE) and studies in eastasian tectonics and resources (SEATAR), U. N. ESCAP, CCOP, Tech. Bull., 123-137, 1980.

Celaya, M. and R. McCabe, Kinematic model for the opening of the Sea of Japan and the bending of the Japanese islands, Geology, 15, 53-57, 1987.

Chase, C. G., Extension behind island arcs and motion relative to hot-spots, J. Geophys. Res., 83, 5385-5387, 1978.

Chen, W. P. and J. Nabelek, Seismogenic strike-slip faulting and the development of the North China basin, Tectonics, 7, 975-989, 1988.

Cobbold, P. R. and P. Davy, Indentation tectonics in nature and experiments, 2, Central Asia, Bull. Geol. Inst.Upsalla, 14, 143-162, 1988.

Davy, P. and P. R. Cobbold. Indentation tectonics in nature and experiments. Experiments scaled for gravity,Bull. Geol. Inst.Upsalla, 14, 129-141, 1988.

Fabbri, O., J. Charvet, and M. Faure, Sur la déformation associée à la rotation de Kyushu (Japon SW) au Miocène Moyen, C. R. Acad Sci. Paris, 304, 1207-1212, 1987.

Faugère, E. and J.P. Brun, Modèlisation expérimentale de la distension continentale, C. R. Acad. Sci. Paris, 299, 365370, 1984.

Faure, M. and F. Lalevée Bent structural trends of Japan, flexural slip folding related to the Neogene opening of the sea of Japan, Geology, 15, 49-52, 1987.

Fukao, Y. and M. Furumoto, Mechanisms of large earthquakes along the eastern margin of the Japan sea, Tectonophysics, 25, 247-266, 1975.

Ganzawa, Y., "Green Tuffs" movement defined by fission-track ages of igneous rocks, 1, Sado Island, J. Geol. Soc. Jpn., 88, 943-956, 1982.

Ganzawa, Y., "Green Tuffs" movement defined by fission-track ages of igneous rocks, 2, Futimoyama area of Toyama prefecture, central Japan, J. Geol. Soc. Jpn.., 89, 271-286, 1983.

Ganzawa, Y., Fission tracks age of volcanic rocks from Cretaceous to Tertiary in the inner belt of northeast Japan, Okushiri island, Oga peninsula and Asahi mountains, $J$. Geol. Soc. Jpn., 93, 387-401, 1987.

Goetze, C. and B. Evans, Stress and temperature in the bending lithophere as constrained by experimental rocks mechanics, Geophys. J.R. Astron. Soc., 59, 463-478, 1979.

Hamburger, M.W. and B. L. Isacks, Diffuse back-arc deformation in the southwestem Pacific, Nature, 332, 599 . 604, 1988.

Harding, T. P., Seismic characteristics and identification of negative flower structures, positive flower structures and positive structural inversions, Am. Ass. Petr. Geol. Bull., $69,582-600,1985$.
Hayashida, A., Timing of rotationnal motion of Southwest Japan inferred from paleomagnetism of the Setouchi Miocene series, J. Geomagn. Geoelectr., 38, 295-310, 1986.

Hilde, T. W. C., S. Uyeda, and L. Kroenke, Evolution of the western Pacific and its margins, Tectonophysics, 38, 145 $165,1977$.

Hilde, T. W. C and J. M. Wageman, Structure and origin of the Japan sea, in, The Western Pacific, Island Arcs, Marginal Seas, Geochemistry, edited by P. J. Coleman , University of Western Australia Press, Perth, pp. 123-137, 1975.

Hirooka, K., H. Sakai, T. Takahashi, H. Kinoto, and A. Takeuchi, Tertiary tectonic movement of central Japan inferred from paleomagnetic studies, J. Geomagn. Geoelectr., 38, 311-323, 1986.

Honza, E. (Ed.), Geological investigation of the Japan sea. April-June 1978 (GH-78-2 cruise), Geol. Surv. Jpn, Cruise Rep.. 13, 99 pp., Geological Survey of Japan, Tsukuba, 1979.

Homafius , J. S., B. P. Luyendik, R. R. Terres, and M. J. Kamerling, Timing and extent of Neogene tectonic rotation in the Western Transverse Ranges, California, Geol. Soc. Am. Bull., 97, 1476-1487, 1986.

Ichikawa, K., Geohistory of the Median Tectonic Line of Southwest Japan, Mem. Geol. Soc. Jpn, 18, 187-212, 1980.

Iijima, A., R. Tada, and Y. Watanabe, Development of Neogene sedimentary basins in the northeastern Honshu arc with emphasis on Miocene siliceous deposits, J. Fac. Sci.Univ. Tokyo, 21, 417-446, 1988.

Ingle, J.C., Summary of Late Paleogene Neogene insular stratigraphy, and correlations, Philippine Sea and sea of Japan region, in Initial Report of DSDP, vol. 31, US Government Printing Office, pp. 837-855, Washington D.C., 1975.

Isezaki, N., A magnetic anomaly map of the Japan sea, $J$. Geomagn. Geoelectr., 38, 403-410, 1986.

Isezaki, N. and S. Uyeda, S., Geomagnetic anomaly pattern of the Japan sea, Mar. Geophys. Res., 2, 51-59, 1973.

Ishikawa, N., and M. Torii, Counterclockwize rotations of the Tsushima and Goto islands, Southwest margin of the Japan Sea, evidences from paleomagnetism, paper presented at 1988 DELP Tokyo International Symposium, Tokyo Intsitute of Technology, Tokyo, Dec. 13-16, 1988.

Ishizuka, H., Greenstones from the Idonnappu formation along the river Oku-Niikappu in the axial zone of Hokkaido, Japan, Mem. Fac. Sci., Kochi Univ., 2, 1-22, 1981.

Ishizuka H., M. Imaizumi, N. Gouchi, and S. Banno, The Kamuikotan zone in Hokkaido, Japan, tectonic mixing of high pressure and low pressure metamorphic rocks, $J$. Metamorph. Geol., 1, 263-265, 1983.

Itoh, Y., Differential rotation of norteastern part of southwest Japan, paleomagnetism of Early to Late Miocene rocks from Yatsuo area in Chubu district, J. Geomagn. Geoelectr., 38, 325-334, 1986.

Itoh, Y., Differential rotation of the eastern part of southwest Japan inferred from paleomagnetism of Cretaceous and Neogene rocks, J. Geophys. Res., 93, 3401-3411, 1988.

Itoh, $Y_{.,}$and $H$. Ito, Tertiary rotational movement of the eastern part of southwest Japan, paleomagnetism and fission-track dating of the Futomiyama Group in the Uozu area, Toyama prefecture, Japan, J. Geol. Soc. Jpn., 94, 11$18,1988$.

Jackson, J.A., Active continental deformation and regional metanorphism, Philos. Trans. R. Soc. London., 321, 4766, 1987.

Jolivet, L., The Hokkaido Central Belt, the succession of tectonic stages, Bull. Soc. Géol. France, 2, 311-327., $1986 a$. 
Jolivet, L., America-Eurasia plate boundary in eastern Asia and the opening of marginal basins, Earth Planet. Sci. Lett., 81 , 282-288, $1986 b$.

Jolivet, L., P.Davy, and P. R. Cobbold, Right-lateral shear along the northwest Pacific margin and the India-Eurasia collision, Tectonics, 9, 1409-1419, 1990.

Jolivet, L. and P. Huchon, Crustal scale strike-slip shear zone in Hokkaido, Northeast Japan, J. Struct. Geol., 11, 509 522, 1989.

Jolivet L. and S. Miyashita, The Hidaka Shear Zone (Hokkaido, Japan), genesis during a right-lateral strike slip movement, Tectonics, 4, 289-302, 1985.

Jolivet, L., P. Huchon, and C. Rangin, Tectonic setting of western Pacific marginal basins. Tectonophysics, 160, 23 48, 1989.

Kang, P. C., Geologic evolution of Korea and structural analysis of Seatar Korean transect area. U. N. ESCAP, CCOP Tech. Bull. 14, 31-51, 1981.

Kawai, N., T. Nakajima, and K. Hirooka, The evolution of the island arc of Japan and the formation of granites in the circum Pacific belt, J. Geomagn. Geoelectr., 23, 267-293, 1971.

Kimura, G., Oblique subduction and collision, forearc tectonics of the Kuril arc, Geology, 14, 404-407, 1986.

Kimura, G. and K. Tamaki, Collision, rotation and back arc spreading, the case of the Okhotsk and Japan seas, Tectonics, 5, 389-401, 1986.

Kimura, G., S. Miyasaka, Y. Kontani, S. Miyashita, K. Hoyanagi, and $Y$. Watanabe, Tectonic significance of the Kamishiyubetsu tectonic line in the uplift of the Hidaka metamorphic belt, Bull. Tectonic Res. Group Jpn., 27, 167177, 1982.

Kimura G., S. Miyashita and S. Miyasaka, Collision tectonics in Hokkaido and Sakhalin, in Accretion Tectonics in the Circum Pacific Region, edited by $\mathrm{M}$. Hashimoto and $\mathrm{S}$. Uyeda, pp.117-128, Terrapub, Tokyo, 1983.

Kobayashi, K. and N. Isezaki, Magnetic anomalies in the sea of Japan and the Shikoku basin, possible tectonic implications, in The Geophysics of the Pacific Ocean and Its Margins, Geophys. Monogr. Ser., vol. 19, edited by G. H. Sutton, M. H Manghnani, and R. Moberly, pp. 235-251, AGU, Washington, D. C., 1976.

Komatsu M., S. Miyashita, J. I. Maeda, Y. Osanai and T. Toyoshima, Disclosing of a deepest section of continental type crust upthrust as the final event of collision of arcs in Hokkaido, North Japan, in Accretion tectonics in the Circum Pacific Regions, edited by M. Hashimoto and S. Uyeda, pp. 149-165, Terrapub, Tokyo, 1983.

Koshiya, S., Tanakura Shear Zone, the deformation process of fault rocks and its kinematics. J. Geol. Soc. Jpn., 92, 15$29,1986$.

Lallemand, S. and Jolivet, L., Japan Sea, a pull apart basin, Earth Planet. Sci. lett., 76, 375-389, 1985.

Lallemand, S., H. Okada, K. Otsuka, and L. Labeyrie, Tectonique en compression sur la marge Est de la Mer du Japon, mise en évidence de chevauchements à vergence orientale, C. R. Acad. Sci. Paris, 301, 201-206, 1985.

Lamb, S. H., Tectonic rotations about vertical axes during the last $4 \mathrm{Ma}$ in part of the New Zealand plate boundary zone, $J$. Struct. Geol., 10, 875-893, 1988.

Lee, J. S., Pétrologie et relations structurales des volcanites Crétacé à Cénozoïques de la Corée du Sud, implications géodynamiques sur la marge est-eurasiatique, Thèse de Doctorat, Université d'Orléans, Orléans, 1989.

Lee, J. S. and A. Pouclet, Le volcanisme néogène de Pohang (SE Corée), nouvelles contraintes géochronologiques pour l'ouverture de la mer du Japon, C.R. Acad. Sci. Paris, 307, $1405-1411,1988$.
Ludwig, W. J., S. Murauchi, and R. E. Houtz, Sediments and structure of the Japan sea. Geol. Soc. Am. Bull., 86, 651664, 1975.

Mandl, G., Tectonic deformation by rotating parallel faults, the "bookshelf" mechanism, Tectonophysics, 141, 277. 316, 1987.

Maritime Safety Agency of Japan, Bathymetric map of Hokkaido, 1: 1000 000, folio 6311, 1980a.

Maritime Safety Agency of Japan, Bathymetric map of northeast Japan, 1: 1000000 , folio 6312, $1980 b$.

Martell, S. J., D. D. Pollard, and P. Segall, Development of simple strike-slip fault zones, Mount Abbot quadrangle, Sierra Nevada, California, Geol. Soc. Am. Bull., 100, 14511465, 1988.

McCabe, R., K. D. Min, J. Han, H. C. Han, and D. Lee, Blocks rotations in southeast and east Asia, paper presented at 1988 DELP Tokyo International Symposium, Tokyo Institute of Technology, Tokyo, Dec. 13-16, 1988.

McKenzie, D., Spinning continents, Nature, 344, 109-110, 1990.

Matsuda, T. and S. Uyeda, On the Pacific type orogeny and its model, extension of the paired belts concept and possible origin of marginal seas, Tectonophysics, 11, 5-27, 1971.

Mitani K., Changing of the Tertiary sedimentary basins in the western flank of the axial belt of Hokkaido- Bearing a significance of the Sunagawa lowland to Umaoi Hilly belt (in Japanese), Assoc. Geol. Collab. Jpn. Monogr, 21, 127. 137, 1978.

Miyashita, S., Reconstruction of the ophiolite succession in the Western Zone of the Hidaka metamorphic belt, Hokkaido, J. Geol. Soc. Jpn., 89, 69-87, 1983.

Moreau, M.G., V. Courtillot, and J. Besse, Evidence for a Miocene widespread remagnetization in northern Japan, Earth Planet. Sci. Lett., 84, 321-338, 1987.

Moriya, T., Seismo tectonics of Hokkaido based on seismicity and focal mechanism studies (in Japanese), Assoc Geol. Collab. Jpn. Monogr., 31, 475-486., 1986.

Murata, A., Conical folds in the Hitoyoshi bending, South Kyushu formed by the clockwise rotation of the Southwest Japan arc. J. Soc. Geol. Jpn., 93, 91-105, 1987.

Nabelek, J., W. P. Chen, and H. Ye, The Tangshan earthquake sequence and its implications for the evolution of the North China basin, J. Geophys. Res., 92, 12615-12628, 1987.

Nakamura, K., Possible nascent trench along the eastern Japan sea as the convergent boundary between Eurasia and North American plates (in Japanese), Bull. Earthquake Res. Inst., 58, 721-732, 1983.

Nakano, N., Metamorphism of the greenstones in the Kamuikotan zone and the Hidaka Westem Marginal tectonic zone in the Shizunai-Mitsuishi district, Hokkaido, J. Geol. Soc. Jpn., 87, 211-214, 1981.

Nur, A., H. Ron, and O. Scotti, Fault mechanics and the kinematics of block rotations, Geology, 14,746-749, 1986.

Okada, H., S. Lallemand, K. Otsuka, and L. Labeyrie, Submarine geologic structure of the eastern margin of the sea of Japan with special reference to the nascent trench problem, Geosci. Rep. Shizuoka Univ., 11, 119-133, 1985.

Osanai, Y., K. Arita, and M. Bamba, P-T conditions of granulite facies rocks from the Hidaka metamorphic rocks, Hokkaido, Japan, J. Geol. Soc. Jpn., 92, 793-808, $1986 a$.

Osanai, Y., S. Miyashita, K. Arita, and M. Bamba, The metamorphism and thermal structure of the collisional terrain of a continental and oceanic crusts, a case of the Hidaka metamorphic belt, Hokkaido, Japan, Assoc. Geol. Collabor. Jpn.Monogr., 31, 205-222, $1986 b$.

Otofuji Y. and T. Matsuda, Paleomagnetic evidence for the clockwise rotation of southwest Japan, Earth Planet. Sci. Lett., 62, 349-359, 1983. 
Otofuji, Y. and Matsuda, T., Timing of rotationnal motion of southwest Japan inferred from paleomagnetism. Earth Planet. Sci. Lett., 70, 373-382, 1984.

Otofuji Y. , T. Matsuda and S. Nohda, Paleomagnetic evidences for the Miocene counter clockwise rotation of northeast Japan - rifting process of the Japan arc, Earth Planet. Sci. Lett., 75, 265-277, 1985.

Otsuki, K., Reconstruction of Neogene tectonic stress field of Northeast Honshu arc from metalliferous veins. Mem. Soc. Geol. Jpn., 32, 281-304, 1989.

Otsuki K. and M. Ehiro M., Major strike slip faults and their bearing on the spreading of the Japan Sea, J. Phys. Earth, suppl. , 26, 537-555, 1978.

Peltzer, G. and P. Tapponnier, Formation and evolution of strike-slip faults, rifts and basins during the India-Asia collision: An experimental approach, J. Geophys. Res., 93, 15085-15117, 1988.

Reedman, A. J. and S. H. Um, The Geology of Korea , 39 pp., Geological Mining Institute, Korea, 1975.

Ron, H., R. Freund, Z. Garfunkel, and A. Nur, Block rotation by strike slip faulting, structural and paleomagnetic evidence, J. Geophys. Res., 89, 6256-6270, 1984.

Rozhdestvenskiy, V. S., The role of wrench faults in the structure of Sakhalin, Geotectonics, 16, 323-332, 1982.

Rozhdestvenskiy, V. S., Evolution of the Sakhalin fold system, Tectonophysics, 127, 331-339, 1986.

Sasajima, S., PreNeogene paleomagnetism of Japanese islands (and vicinities), in Paleoreconstructions of the Continents, Geodynam. Ser., vol. 2, edited by M. W. Mac Elhinny and D. A. Valencio, pp. 115-128, AGU, Washington, D. C., 1981.

Sayanagi, K., N. Isezaki, and Y. Kitahara, Report on DELP 1985 cruises in the Japan Sea, IV, Geomagnetic anomalies over the seamounts in the Yamato Basin, Bull. Earthquake Res Inst., Univ. Tokyo, 62, 391-415, 1987.

Schluter, H. U. and W. C. Chun, Seismic survey off the east coast of Korea, U. N. ESCAP, CCOP Tech. Bull., 8, 1-15, 1974.

Shibata K., K/Ar age determinations on granitic and metamorphic rocks in Japan, Rep. Geol. Surv. Jpn., 227, 173, 1968.

Shibata $\mathrm{K}$. and S. Ishihara, Rb/Sr whole rock and $\mathrm{K} / \mathrm{Ar}$ mineral ages of granitic rocks in Japan, Geochem. J., I3, 113-120, 1979.

Shibata, K., S. Uchiumi, K. Uto, and T. Nakagawa, K-Ar results, 2, New data from the geological survey of Japan, Bull. Geol. Surv. Jpn., 35, 331-340, 1984.

Sillitoe, R. H., Metallogeny of an Andean type continental margin in South Korea, implications for opening of the Japan Sea, in Island Arcs, Deep Sea Trenches and Back Arc Basins, Maurice Ewing Ser., vol. 1, edited by M. Talwani and W. C. Pitman III, pp. 303-310, AGU, Washington, D. C., 1977.

Tamaki, K., Two modes of back arc spreading, Geology, 13, 475-478, 1985.

Tamaki, K., Age estimation of the Japan Sea on the basis of stratigraphy, basement depth and heat flow data, $J$. Geomagn. Geoelectr., 38, 427-446, 1986.

Tamaki, K., Geological structure of the Japan Sea and its tectonic implications, Bull. Geol. Surv. Jpn., 39, 269-365, 1988.

Tamaki, K. and E. Honza, Incipient subduction and obduction along the eastern margin of the Japan Sea, Tectonophysics, 119, 381-406, 1985.
Tapponnier, P. and P. Molnar, Slip-line field theory and large scale continental tectonics, Nature, 264, 319-324, 1976.

Tapponnier, P., G. Peltzer, A. Y. Le Dain, R. Armijo, and P. Cobbold, Propagating extrusion tectonics in Asia, new insights from simple experiments with plasticine, Geology, 10, 611-616, 1982.

Tapponnier, P., G. Peltzer, and R. Armijo, On the mechanics of the collision between India and Asia, Geol. Soc. Spec. Publ., 19, 115-157, 1986.

Taylor, B. and G. D. Karner, On the evolution of marginal basins, Rev. Geophys. , 21, 1727-1741, 1983.

Tosha, T., Paleomagnetism of northeast Japan. Ph.D. thesis, 77 pp., Univ. of Tokyo, 1983.

Tosha, T. and Y. Hamano, Paleomagnetism of Tertiary rocks from the Oga peninsula and the rotation of northeast Japan, Tectonics, 7, 653-662, 1988.

Uda, T., Deformation of granitic pebbles in "Utaro conglomerate" at cape Erimo, Hokkaido, Japan, J. Geol. Soc. Jpn., 79, 391-398, 1973.

Uda, T., Polyphase deformation of the Cape Erimo area by change of tectonic stress field. J. Geol. Soc. Jpn., 82, 1-18, 1976.

Uyeda, S., Facts, ideas and open problems on trench-arc-back arc systems, in The Origin of Arcs, edited by F.C. Wezel, pp. 435-460, Elsevier Science, New York, 1986.

Uyeda S. and H. Kanamori, Backarc opening and the mode of subduction, J. Geophys. Res., 84, 1049-1061, 1979.

Vendeville, B., P. R. Cobbold, P. Davy, J. P. Brun, and P. Choukroune, Physical models of extensional tectonics at various scales, Geol. Soc. London Spec. Publ., 28, 95-107. 1987.

Walcott, R. I., The kinematics of the plate boundary zone through New Zealand, a comparison of short and long term deformation, Geophys.J. R. Astron. Soc., 79, 613-633, 1984.

Walcott, R. I., Geodetic strain and the deformational history of the North island of New Zealand during the Late Cainozoic, Philos. Trans. R. Soc. London, 321, 163-181, 1987.

Watanabe, Y., Deformation structure of the Uenshiri horst in the Hidaka belt, Central Hokkaido, J. Geol. Soc. Jpn., 94. 527-533, 1988.

Watanabe $Y$. and $K$. Iwata, The age of the Miocene Kamishiyubetsu formation in northern Hokkaido and the basins formed by tectonic movements, J. Geol. Soc. Jpn., 91, 427-430, 1985.

Yamagishi, H. and Y. Watanabe, Change of stress field of Late Cenozoic Southwest Hokkaido, Japan, investigation of geologic faults, dykes, ore veins and active faults. Geol. Collabor. Jpn. Monogr., 31, 321-332, 1986.

Yamaji, A., Geology of the Atsumi area and Early Miocene rifting in the Uetsu District, Northeast Japan, Mem. Geol. Soc. Jpn., 32, 305-320, 1989.

J.P. Brun, Laboratoire de Tectonique, Université de Rennes 1, Avenue du Général Leclerc, 35042, Rennes Cedex, France. N. Chamot-Rooke, P. Huchon, L. Jolivet, X. Le Pichon and J.C. Thomas, Département de Géologie, Ecole Normale Supérieure, 24 rue Lhomond, 75231 Paris Cedex, France.

(Received April 17, 1989; revised April 16, 1990; accepted July 5, 1990.) 